\title{
Measuring urban form at community scale: Case study of Dublin, Ireland
}

\author{
Zorica Nedovic-Budic ${ }^{\mathrm{a}, *}$, Gerrit Jan Knaap ${ }^{\mathrm{b}}$, Harutyun Shahumyan ${ }^{\mathrm{a}, \mathrm{b}}$, Brendan Williams ${ }^{\mathrm{a}}$, Aleksander Slaev ${ }^{\mathrm{c}}$ \\ ${ }^{\text {a } U n i v e r s i t y ~ C o l l e g e ~ D u b l i n, ~ B e l f i e l d, ~ D u b l i n ~ 4, ~ I r e l a n d ~}$ \\ b University of Maryland, College Park, MD 20742, USA \\ c Free Varna University, Bulgaria
}

\section{A R T I C L E I N F O}

\section{Article history:}

Received 6 July 2015

Received in revised form 16 February 2016

Accepted 24 February 2016

Available online 12 March 2016

\section{Keywords:}

Urban form measures

Urban sprawl

Community scale

Street connectivity

Density

Land use mix

Dublin

\begin{abstract}
A B S T R A C T
With a tradition of compact cities, generally strict planning controls, and variable growth rates, many cities in Europe have policies which aim to restrict low density growth patterns. However, there is clear evidence that low density growth is happening, and that it is essential to understand the nature, location, and extent of the urban forms emerging on the periphery of cities across Europe. In its extreme manifestation, such low density peripheral growth is labelled as sprawl and considered detrimental. Drawing on the extensive literature on defining and measuring urban form, we focus on the methodologies and measures applied in the European studies at the regional (metropolitan), city, and community level. Affirming that the assessment of urban form at the community level is undertaken only sporadically, we adapt the measures used by Knaap et al. (2007) in studying US urban form to explore their applicability and robustness in analysing the evolution of urban form in a European setting. We examine the change of urban form in the Dublin Region (Ireland) in terms of residential and commercial density, internal and external connectivity, and land use mix. We find that the measures used, when adjusted to meet availability and nature of local data, are strong in revealing the trends in urban development form. We conclude by discussing the significance of the trends revealed in the case of Dublin and point to the issues of data availability in terms of both spatial and temporal resolution. Finally, we speculate on how the measures at different scales are suited to inform different types of urban policies and planning approaches.
\end{abstract}

(c) 2016 Elsevier Ltd. All rights reserved.

\section{Introduction}

Over the course of time, cities inevitably tend to grow due to both the natural increase of population and immigration from other areas rural and urban, internally or internationally. Due to the changing norms and ideals of what is the acceptable quality of life in cities many urban areas worldwide have seen a changing dynamic in urban growth, with the tendency toward suburban forms and lower densities (Hall, 2002; Barrington-Leigh \& Millard-Ball, 2015). Brought to an extreme, the suburban low density developments could turn into urban sprawl - a phenomenon that emerged in the United States following WWII and subsequently extended to other world regions, 'western' countries in particular (Fishman, 1987; Jackson, 1985).

Urban sprawl started to emerge in Europe in 1950s with the appearance, extent and pace varying by region (Antrop, 2004; Fons, 2012). Despite the evidence of negative birth rates and urban shrinkage in some regions (Wiechmann \& Pallagst, 2012), European cities are growing,

\footnotetext{
* Corresponding author.

E-mail addresses: zorica.nedovic-budic@ucd.ie (Z. Nedovic-Budic),gknaap@umd.edu (G.J. Knaap), harutyun.shahumyan@ucd.ie (H. Shahumyan), brendan.williams@ucd.ie (B. Williams), slaev@vfu.bg (A. Slaev).
}

with population increases in the recent decades primarily based on the national born population, and identified as most intense in smaller, amenity-rich, lower density and affluent cities (Bosker \& Marlet, 2006). However, the nature of such growth has been changing over the past six decades. Based on a sample of 24 cities European Environmental Agency (EEA, 2006) reports the trend of urban sprawl across European cities, including 'countries or regions with high population density and economic activity (Belgium, the Netherlands, southern and western Germany, northern Italy, the Paris region) and/or rapid economic growth (Ireland, Portugal, eastern Germany, the Madrid region' (p. 9). At the local level, in some of the sampled cities, $90 \%$ of development since mid-1950s is in form of low density residential development. In addition to countryside, mountainous and coastal regions are also under threat of sprawl. In the 1990-2000 decade alone, urbanisation of coastal areas surpasses urbanisation of inland areas by $30 \%$, with Portugal, Ireland and Spain topping the list (EEA, 2006).

Clearly, suburban and somewhat dispersed growth is observed in some of the major and traditionally dense European urban areas. Concomitant with suburbanization is the decline of central cities, Hamidi and Ewing (2014) offer examples of both Barcelona and Milan experiencing substantial population loss - citing Barcelona with the largest loss of central city population in Europe in the last 25 years; 
Milan losing a population of 600,000 to urban periphery in the last 15 years. Rome provides an additional example in the southern European context, with its suburban population growth of $30 \%$ (i.e., over 100,000) between early 1990s and 2011, paralleled by a loss of population in historic city centre and its immediate surrounding (ISTAT, 2012). Interestingly, in post-communist eastern and central Europe too, suburban sprawl has been quick to replace high density housing estates as a desired development pattern at the periphery of major cities (Kok \& Kovács, 1999; Krisjane \& Berzins, 2012; Stanilov \& Sýkora, 2014).

Overall, there is initial evidence that Europe is prone to sprawl and potentially affected by the related inefficient consumption of natural resources and energy and impacts in terms of environmental, economic, and social dynamics (EEA, 2006). However, valid and accurate measures of both the urban development patterns and the impacts on urban form resulting from those developments are not easy to establish. These observations are generally challenged by the complexity and multiplicity of factors and forces associated with urban growth and difficulties in assessing them. The breadth, multifaceted nature and the lack of universally accepted definitions are obstacles to the comprehensive treatment of the issue of sprawl, as well as to deriving consistent and comparable research findings (Wilson \& Chakraborty, 2013). Johnson (2001) maintains that these difficulties hamper the research on methodological issues. However, regardless of the methodological difficulties, researchers in the USA have made significant progress in measuring urban sprawl and distinguishing it from other more traditional types of urban development (Brueckner, 2000, Galster et al., 2001; Nechyba \& Walsh, 2004; Hamidi \& Ewing, 2014). These sources also include works that measure urban form at community scale where the impact on quality of life is most strongly manifested and felt (Southworth \& Owens, 1993; Wheeler, 2003; Song \& Knaap, 2004; Knaap, Song, \& Nedovic-Budic, 2007; Barrington-Leigh \& Millard-Ball, 2015).

In the European context, empirical studies at intra-urban scale are rare for reasons including but not limited to a lack of detailed datasets and focus on regional level indicators and scales (e.g., by ESPON ${ }^{1}$ ), widely varying methodologies and definitions between European countries of what represents an urban settlement, and possibly some disregard for the serious nature of the problem (EEA's 2006 report terms urban sprawl issue as an 'ignored challenge'). To contribute to a better understanding of the nature of European urban sprawl, we review the existing methodological work on measuring urban form and focus on the community level to test a selection of indicators in a case study of Dublin, Ireland. This case is chosen for its substantial suburban and dispersed development at the urban-rural interface observed over the past two decades (Ellis \& Kim, 2001; EEA, 2006; Gkartzios \& Scott, 2009; McInerney \& Walsh, 2009). To measure the change in Dublin's urban form, we trace the developments from pre-1950 to 2006 using land cover data along with topographic maps and local scale postal and socio-economic data. Toward that end we apply five measures adapted from the methodology used by Knaap et al. (2007) - internal and external street network connectivity, residential and commercial density, and land use mix. We conclude the paper by discussing the nuances of understanding and measuring urban sprawl at the community scale in the European context and by suggesting that measurements at different levels are informative and suitable for different types of urban planning and policy interventions.

\section{Urban form and sprawl: alternative perspectives, definitions and measures}

Urban form is primarily a spatial construct inextricably related to the patterns of development and human activity. It is often defined in terms

\footnotetext{
${ }^{1}$ European Spatial Planning Observation Network - http://www.espon.eu/.
}

of connectivity (street network, transportation); land use types, intensity, mix and proximity; population and employment density and distribution (concentration, centralisation, clustering); and contiguity (dispersion, fragmentation) and shape of the built environment. The various characteristics of urban form are measured either individually or combined as indexes or coefficients. The form could be assessed with a range of methods, including: remote sensing, density gradients and gravity measures, fractals, entropy measures, surfacebased approaches, geometrical techniques, architectural and photogrammetric techniques, measurements of landscape composition and spatial configuration, and accessibility calculations (Torrens \& Alberti, 2000; Tsai, 2005). Along with various processes and functions associated with urban morphology, the social aspect of urban form is also recognised as important for understanding urban experience and for pursuing various actions in urban environments (Le Goix, 2005; Kirby, 2008; Chakraborty, 2009).

Urban sprawl refers to a specific type of urban form, often mentioned under various terms, such as discontinuous suburban growth, linear patterns of development (strip), leapfrogging or dispersed (scattered) development (Ewing, 1994; Ewing, 1997; Peiser, 2001; Hamidi \& Ewing, 2014). Chin (2002) maintains that urban sprawl is the anti-thesis of the compact city, which is characterised by high density, centralised development and a mix of spatial functions. The author outlines four different types of definitions of urban sprawl based on: urban form, land use, impacts and density. Galster et al. (2001) find in various sources that the term sprawl relates to pattern, process, causes and consequences, and that a number of definitions are available. Besussi, Chin, Batty, and Longley (2010) define sprawl as the rapid and uncontrolled spreading of urban settlements at their fringes.

In the European context, a comprehensive definition of urban sprawl is given by the European Environment Agency (EEA, 2006):

"Urban sprawl is commonly used to describe physically expanding urban areas. The European Environment Agency (EEA) has described sprawl as the physical pattern of low-density expansion of large urban areas, under market conditions, mainly into the surrounding agricultural areas. Sprawl is the leading edge of urban growth and implies little planning control of land subdivision. Development is patchy, scattered and strung out, with a tendency for discontinuity. It leap-frogs over areas, leaving agricultural enclaves. Sprawling cities are the opposite of compact cities - full of empty spaces that indicate the inefficiencies in development and highlight the consequences of uncontrolled growth." (p. 6)

The EEA's definition, although not elegant, encompasses a description of the physical appearance of sprawl as a particular type of urban form and suggests conditions that lead to it as well as the ensuing inefficiencies. Inherently, urban sprawl is connected to the process of development, which aligns with Couch, Leontidou, and Petschel-Held (2007) view of sprawl as not only a spatial pattern of urbanisation, but as a process of urban change. Even with many alternative perspectives on sprawl the European and non-European sources seem to agree on the main characteristics of urban sprawl, summarised by Nedovic-Budic, Slaev, Krunic, and Petric (2015) in Table 1. These characteristics include: a) decreasing overall densities, and low and/or falling suburban densities; b) dispersed, leapfrogging or ribbon suburban form; c) over-developed road networks, car dependence, and poor access; and d) poor mix of uses, and lack of well-defined centres with services and public amenities.

Clifton, Ewing, Knaap, and Song (2008) provide a comprehensive review and classification of perspectives used to characterise urban form: landscape ecology, economic structure, transportation planning, community design, and urban design. The dimensions of urban form associated each of these perspectives are variably manifest at community (neighbourhood, block), citywide and metropolitan scales 
Table 1

Summary of sources concerning key characteristics of sprawl.

(Adopted from Nedovic-Budic et al., 2015).

\begin{tabular}{|c|c|c|c|}
\hline $\begin{array}{l}\text { Decreasing overall densities; } \\
\text { Low and/or decreasing } \\
\text { suburban densities }\end{array}$ & $\begin{array}{l}\text { Dispersed, leapfrogging } \\
\text { or ribbon suburban forms }\end{array}$ & $\begin{array}{l}\text { Over-developed road networks; } \\
\text { Car dependence; } \\
\text { Poor access }\end{array}$ & $\begin{array}{l}\text { Poor mix of uses; Lack of well-defined } \\
\text { centres with services and public } \\
\text { amenities }\end{array}$ \\
\hline $\begin{array}{l}\text { Knaap, 1998; } \\
\text { Nivola, 1998; } \\
\text { Pendall, 1999; } \\
\text { Brueckner, 2000; } \\
\text { Fulton, Pendall, Nguyen, \& Harrison, 2001; } \\
\text { Galster et al., 2001; } \\
\text { Ewing, Pendall, \& Chen, 2002; } \\
\text { Sudhira, Ramachandra, \& Jagadish, 2003; } \\
\text { Song \& Knaap, 2004; } \\
\text { EEA, 2006; } \\
\text { Couch et al., } 2007\end{array}$ & $\begin{array}{l}\text { Galster et al., 2001; } \\
\text { Yeh \& Li, 2001; } \\
\text { Ewing et al., 2002; } \\
\text { Song \& Knaap, 2004; } \\
\text { EEA, 2006; } \\
\text { Frenkel \& Ashkenazi, } 2008\end{array}$ & $\begin{array}{l}\text { Nivola, 1998; } \\
\text { Brueckner, 2000; } \\
\text { Torrens \& Alberti, 2000; Gordon \& Richardson, 2001; } \\
\text { Ewing et al., 2002; } \\
\text { Galster et al., 2001; } \\
\text { Song \& Knaap, 2004; } \\
\text { EEA, 2006; } \\
\text { Buehlera \& Pucherb, } 2012\end{array}$ & $\begin{array}{l}\text { Nivola, 1998; } \\
\text { Knaap, 1998; } \\
\text { Ewing et al., 2002; } \\
\text { Song \& Knaap, 2004; } \\
\text { Keys, Wentz, \& Redman, } 2007\end{array}$ \\
\hline
\end{tabular}

(Tsai, 2005). ${ }^{2}$ The listed characteristics of urban sprawl have been examined under these various perspectives and confirmed in a number of studies and at various scales.

In Europe, relevant research on urban growth has been undertaken through a number of projects, but primarily at the city or regional scales. Drawing on the landscape ecology perspective and by assessing landuse change across 26 European countries Siedentop and Fina (2012) suggest a substantial variability in terms of urban growth and its territorial shape. Differences are found across countries and regions in terms of the intensity of urbanisation, the pace of urban growth, and the spatial pattern of land consumption. The authors argue that these differences could not be explained by varying demographic or economic growth pressures alone. They use indicators on the composition, pattern, and density of urban growth to illustrate that country-specific drivers of urban land-use change play an important role for the shaping of Europe's settlement structure.

The European Commission funded project, Sprawling Cities And TransporT from Evaluation to Recommendations (SCATTER) ${ }^{3}$ takes the transportation perspective. The project examines urban sprawl by using both qualitative and quantitative methods on a sample of six European cities and particularly focusing on the relationship with provision of transportation infrastructure. The results of the modelling undertaken in the project suggest that sprawl may be associated even with cities which are on an economic and population decline (Besussi et al., 2010). This would suggest that the relocation of population within an urban area rather than growth is contributing to the peripheral low density expansion of cities.

Assuming principally an economic perspective, a study by Patacchini and Zenou (2009) relies on the Urban Audit ${ }^{4}$ dataset from EUROSTAT to examine the differences in indicators such as population size, density, economic conditions, human capital, and amenities in the European context. They find that northern European cities, which are typically

\footnotetext{
2 - Landscape ecology methods contribute primarily in identifying patches and diversity of various land covers and lead to understanding of possible fragmentation of urban development;

- Economic structure perspective focuses on the economic efficiency of an urban (metropolitan) region in terms of size, population density and employment, diversity and polycentricity as well as related land values;

- Transportation planning perspective is focused on the movement of goods and people and overall accessibility within an urban region by various modes of travel, as they relate to the configuration of street network and other transport infrastructure;

- Community design is a more recent approach tailored to the scale needed to plan for smart growth and based on analyses of localised (e.g., neighbourhood) patterns of land use, connectivity and accessibility; and

- Urban design measures are of very local scale and focus on the physical features, accessibility, and aesthetics as they related to human interactions, perceptions, and urban experience.

3 http://www.casa.ucl.ac.uk/scatter.

${ }^{4}$ Urban Audit provides information and comparable measurements on the different aspects of the quality of urban life in European cities (http://epp.eurostat.ec.europa.eu/ portal/page/portal/region_cities/city_urban).
}

larger and have more substantial historic centres, are slower to decline in density than generally smaller southern European cities. This is in line with already mentioned problem of uncontrolled peripheral growth in post-communist southeast Europe. Also the authors find that the smaller cities are expanding more than the large cities, which confirm the results of Bosker and Marlet (2006) who find that minor, amenityrich and affluent cities are growing faster.

Probably the most comprehensive study of the European urban form at a city scale is conducted by Schwarz (2010) who employs 41 indicators drawing on the landscape ecology and economic perspectives. The author analyses 228 European cities using the Urban Audit and CORINE Land Cover $^{5}$ datasets. She identifies eight classes of cities ranging from those that are characterised by compact development, to cities varying in size and population density; extent of discontinuous urban fabric; number, size and scattering of urban patches; compactness of the city and the patches; and edge densities. Interestingly, the classes bear no correspondence with the national boundaries, as cities in each class are found across several countries or regions.

While the studies at the city and metropolitan scale are prevalent both in the U.S. and Europe, fewer studies tackle the local community scale and apply indicators that connect more directly to the principles and criteria used to define urban form. The more limited number of studies in the European sphere includes the work performed by Batty and Longley (1994) on the fractal nature of urban morphology based on the geometry and evolution of different land uses over time; and Burton's (2000) evaluation of urban form of twenty-five UK cities against the social equity criteria such as access to jobs and amenities, use of public transport, housing affordability, health, segregation, and crime. While the fractal work demonstrates its practical value primarily in simulating the organic growth of urban forms, the latter provides a nuanced account of a relatively weak relationship between compactness and social justice indicators when aggregated, but significant positive and negative relationships with specific dimensions of social equity.

In North America several studies have been conducted to measure urban form at community scale based on either previously established indicators of urban form or newly defined variables, depending on the extent and scope of their research. An early comprehensive study of sprawl in the United States to delve into the relationship between urban sprawl and form based on quantitative analysis is by Ewing et al. (2002). The authors use census, transport, commuting, and quality of life data along with graphical street network and urban block files $\left(\right.$ TIGER $^{6}$ ) to create a Sprawl Index based on four factors: residential density; neighbourhood mix of homes, jobs and services; strength of

\footnotetext{
5 Co-ORdinated INformation on the Environment (CORINE) Land Cover data series (http://land.copernicus.eu/pan-european/corine-land-cover).

${ }_{6}$ Topologically Integrated Geographic Encoding and Referencing - files produced by US Bureau of the Census (https://www.census.gov/geo/maps-data/data/tiger.html).
} 
activity centres and downtowns; and accessibility of the street network. The authors aggregate the local data to rank eighty-three metropolitan areas based on their average score. In a series of papers Knaap et al. (2007) and Song and Knaap (2004) provide a methodological breakthrough by introducing parcel-level data and GIS-based analysis in measuring community scale variables: development density and intensity; land use mix; street network patterns (design and connectivity); residential proximity to local commercial activities, amenities and bus services; and pedestrian access. They report results from Oregon, Minnesota, Arizona, Maryland and Florida. In Portland, Oregon, they discover a statistically significant improvement in neighbourhood urban form in the areas developed with 'new urbanist' principles relative to the traditional pre-1990s suburban neighbourhoods. However, the authors do not examine the determinants of such positive change, which could be traced to both market forces and planning policies. In comparing the cases across the states (Oregon - Portland Metropolitan Area, Minnesota - St. Paul-Minneapolis Metropolitan Area, Arizona Maricopa County, Maryland - Montgomery County, and Florida - Orange County) their research suggests that urban forms vary within and across study areas and also over time, pointing to the complexity and challenges in applying composite measures. They find general trends, some of which suggest a trend away from sprawl (e.g., increased internal connectivity and density) while other suggest a continuation of suburban fragmentation and sprawl (e.g., separation of land uses, falling pedestrian accessibility to commercial uses, and more isolated neighbourhoods).

Taking the transportation perspective and also focusing on the community design level, Southworth and Owens (1993) and Wheeler (2003) examine the local street pattern as an indicator of evolving morphologies at the urban edge through the 20th century, the former using the case of San Francisco Bay area and the latter comparing Toronto and Portland. Both authors affirm the substantial decrease over time of the network density and its connectivity to the surrounding developments. Wheeler contends that even though leapfrogging happens even during the streetcar era, the traditional grid pattern allowed for linking of neighbourhoods as they filled in. From the historical analysis, the author concludes that the following design principles could promote the return to sustainable urban form: compactness, contiguity, connectivity, diversity and ecological integration. Indeed, a recent study by Barrington-Leigh and Millard-Ball (2015) provides strong evidence that the trend in lowering connectivity is reversing, and that this reversal is due to the planning policies which more forcefully promote and enforce a traditional street design (e.g., New Urbanism).

Although the studies may differ in the ways they approach and measure the physical characteristics of local communities (e.g., neighbourhoods), they overlap substantially in terms of indicators used. The summary of indicators used in the mentioned studies and other predominantly North American sources is presented in Table 2. These indicators revolve around the concepts of: density, land use mix, connectivity, accessibility and ecological design.

Empirical studies of more detailed urban form and trends in urban change at the local community scale are sporadic in the European research portfolio. Building on the previous work of scholars in the U.S.A., we proceed to examine the applicability of several key community level indicators in the European context, and specifically by studying the evolution of urban form in Dublin Region from pre-1950 to 2006. We replicate the methodology developed by Song and Knaap, and focus on necessary adaptation of the sourced data in order to provide a comparable study to the extent possible with the data available.

\section{Applying community level measures in the European context: the case of Dublin Region}

With numerous approaches, measures and datasets used in previous studies to assess urban form, in this paper we contribute to this body of knowledge by applying in the European context several community scale measures used by Knaap et al. (2007) in a comparative study of four cities in the U.S. We focus on the Dublin Region which is noted as the "worst-case scenario" of urban sprawl and used as a negative example for planners in Europe, in the emerging eastern European cities in particular (EEA, 2006). We aim to capture the nature of change in Dublin's urban form from pre-1950 to 2006 using measures of connectivity, density and land use mix. More importantly, we are to examine if those measures are transferable to a European context and revealing of the urban growth and development around Dublin.

\subsection{Study area}

The Greater Dublin Region (GDR), which encompasses Dublin City and the counties of Dublin, Louth, Meath, Kildare and Wicklow, is Ireland's most densely populated region with a population of 1.9 million ( $42 \%$ of the State) over $7800 \mathrm{~km}^{2}$ (Fig. 1, left). As the main urban node of the GDR, Dublin is Ireland's largest city, with 2011 population of 527,000 in the city proper and 1.273 million when the surrounding suburbs are counted (also known as Dublin Region, Fig. 1 right; CSO, 2012). We focus our analysis on spatial development patterns of Dublin Region, which comprises the constituent administrative areas of Dublin City Council, South Dublin County Council, Dún Laoghaire-Rathdown County Council and Fingal County Council. The Dublin Region with the area of $923 \mathrm{~km}^{2}$ housed $27.8 \%$ of the total residents of the State in 2011 and has historically maintained this primacy f (Fig. 1, right). In the same year, the population density for Dublin Region was 1380 persons per $\mathrm{km}^{2}$, which would put it at a lower end of the European range of urban population densities (Eurostat, 2014, EC, 2011).

\subsection{Context}

Post-WWII Ireland has been developing slowly, with limited economic development in the 1960s and 1970s followed by a major recession and decline in the 1980s shared with the rest of Western Europe (MacLaran, 1984). Since the early 1990s, Ireland experienced unprecedented social, economic and demographic changes (Sweeney, 1998, 2008). Assisted by an influx of European structural funds, between 1994 and 2000 Ireland saw an annual average growth rate in real GDP of over 7\% and a rise of employed people from 1.2 million in 1994 to 2.1 million by 2007; the unemployment rate fell to just over $4 \%$ in 2000 and remained at this level until 2008 (Franzini et al., 2013). This economic boom was commonly referred as the 'Celtic Tiger'. The growth in Ireland and Irish cities from the early 1990s, has been based to a large extent on high domestic birth rates, but also on substantial national migration and international immigration (Hughes, McGinnity, O'Connell, \& Quinn, 2008). The GDR is considered the principal beneficiary of the 'Celtic Tiger' years (Couch et al., 2007) with imbalances in regional socio-economic development evident (Meredith \& van Egeraat, 2013). During approximately 15 years from early 1990s to 2007, the GDR and more specifically Dublin Region experienced the greatest transformations in terms of both urban redevelopment and new growth (Foley, Williams, Cudden, \& Shahumyan, 2012; Petrov, Shahumyan, Williams, \& Convery, 2013; Petrov, Shahunyan, Williams, \& Convery, 2011; Shahumyan, Williams, \& Foley, 2013; Shahumyan et al., 2011; Williams, 2011). Dublin has been the focus and the driver of most of the growth (Williams, Foley, Cudden, \& Shahumyan, 2012), although urban development extended to other Irish cities and regions, including considerable intrusion in rural communities and landscapes (Gkartzios \& Scott, 2009; McInerney \& Walsh, 2009).

During this period the Dublin Region gained an additional quarter million inhabitants; was connected to its hinterland by an orbital/ring road (M50), port tunnel and a series of motorways; expanded its airport; developed a major IT sector; and become an international financial services provider (Williams et al., 2012). Also, Dublin underwent a 
Table 2

Measures of urban form at community scale.

\begin{tabular}{|c|c|c|c|}
\hline $\begin{array}{l}\text { S. } \\
\text { no. }\end{array}$ & Measures & Concept & Sources \\
\hline 1. & Density & $\begin{array}{l}\text { Average number of residential, commercial or other units per square } \\
\text { unit of developed land }\end{array}$ & $\begin{array}{l}\text { Burton (2000), Galster et al. (2001), Ewing et al. (2002), Krizek (2003), Wheeler } \\
\text { (2003), Jabareen (2006) }\end{array}$ \\
\hline 2. & $\begin{array}{l}\text { Land use } \\
\operatorname{mix}\end{array}$ & $\begin{array}{l}\text { Degree to which different land uses (and/or related functions) } \\
\text { commonly exist within same smaller area }\end{array}$ & $\begin{array}{l}\text { Batty and Longley (1994), Burton (2000), Galster et al. (2001), Camagni, Gibelli, } \\
\text { and Rigamonti (2002), Ewing et al. (2002), Krizek (2003), Jabareen (2006), Song } \\
\text { and Knaap (2004), Knaap et al. (2007) }\end{array}$ \\
\hline 3. & Connectivity & $\begin{array}{l}\text { Directness of links and the density of connections in a street and/or } \\
\text { transport network }\end{array}$ & $\begin{array}{l}\text { Southworth and Owens (1993), Camagni et al. (2002), Ewing et al. (2002), Krizek } \\
\text { (2003), Wheeler (2003), Jabareen (2006), Song and Knaap (2004), Knaap et al. } \\
\text { (2007), Barrington-Leigh and Millard-Ball (2015) }\end{array}$ \\
\hline 4. & Accessibility & $\begin{array}{l}\text { Ability to reach commercial, social, leisure and employment } \\
\text { destinations from home and access to pedestrian, biking and other } \\
\text { transport systems }\end{array}$ & $\begin{array}{l}\text { Hess, Moudon, Snyder, and Stanilov (1999), Burton (2000), Bertaud (2001), Galster } \\
\text { et al. (2001), Ewing et al. (2002), Song and Knaap (2004), Knaap et al. (2007) }\end{array}$ \\
\hline 5. & $\begin{array}{l}\text { Ecological } \\
\text { design }\end{array}$ & $\begin{array}{l}\text { Land cover that has not been developed in an urban region and is of } \\
\text { environmental importance/benefit }\end{array}$ & Wheeler (2003), Jabareen (2006), Knaap et al. (2007) \\
\hline
\end{tabular}

substantial rejuvenation of its inner city areas with multiple major projects including at Temple Bar and the Docklands - the last becoming internationally known as an example of urban regeneration (Moore, 2008).

New housing construction outside the economic core areas was supported with the availability of easy credit and mortgages, as well as the development of new motorways which continually pushed employmentrelated housing demand to areas of further distances from Dublin (Kitchin, Hearne, \& O'Callaghan, 2015). This resulted in the dispersal of housing, retail and employment activities in a fragmented manner across the GDR (Williams \& Redmond, 2014). Indeed, the continuous and uncontrolled outward sprawl of the city has exacerbated the environmental and service provision challenges for the inhabitants of the Dublin Region, as they confront problems like traffic congestion, pollution and poor infrastructure facilities (Williams \& Shiels, 2000; Williams, Walsh, \& Boyle, 2010; Williams \& Redmond, 2014).

The weight of rapid urban growth with inadequate infrastructure put limitations on a future planned and effective physical growth of Dublin and its impact on Ireland. However, in 2009, the great financial crisis had a major impact on the Irish economy. A property market crash caused by a combination of high levels of speculation and oversupply resulted in the need for a complete government rescue of the Irish banking sector and a period of severe austerity. The economy and development market have experienced a major downturn with all construction activity stalled with a partial recovery developing from 2014/2015. While it is evident that the consequences of the dispersed development would have long-term bearing on future development and environmental policies, the crisis has created the opportunity for
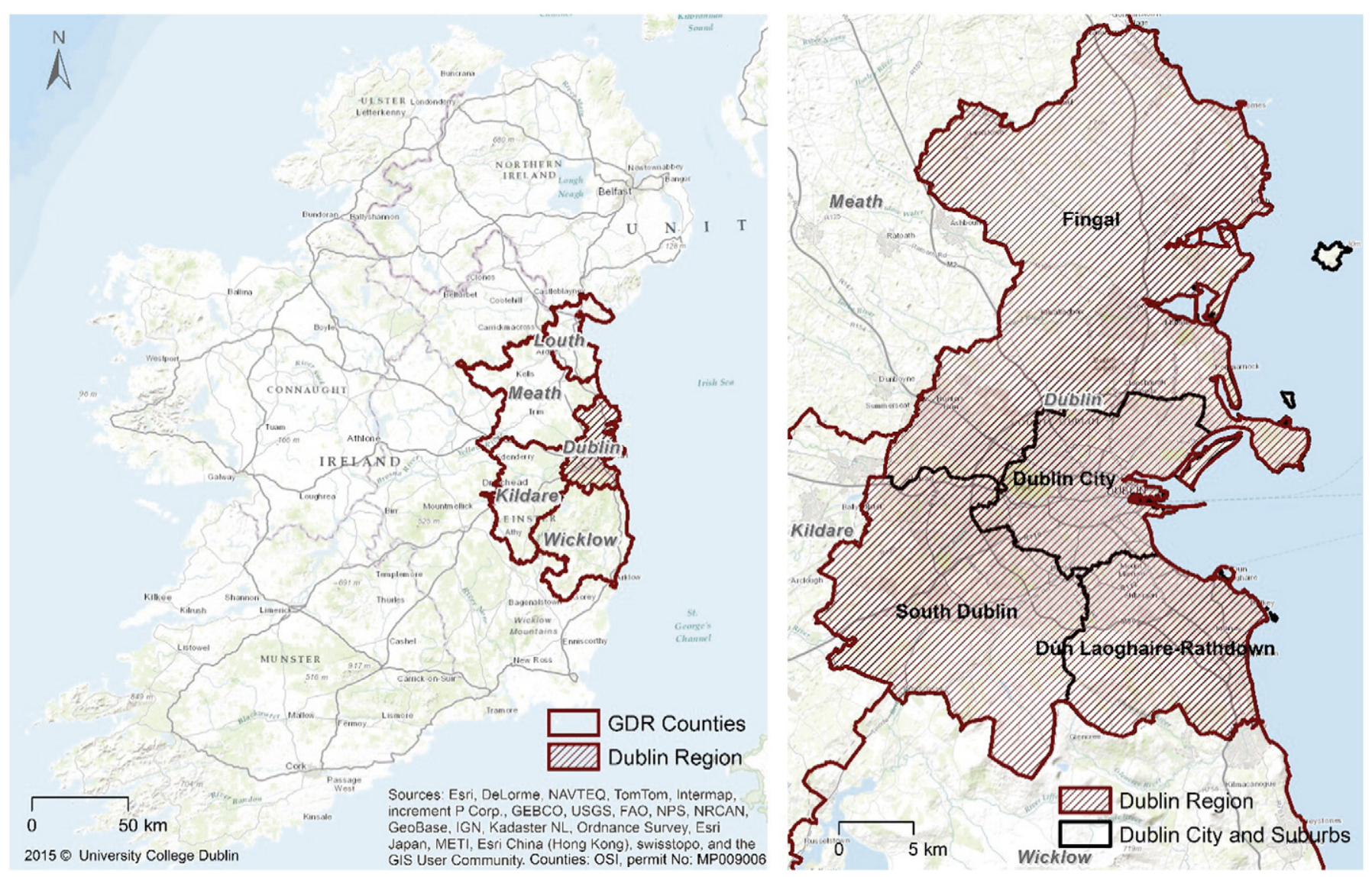

Fig. 1. Greater Dublin Region in the context of Ireland (left) and Dublin Region (right). 

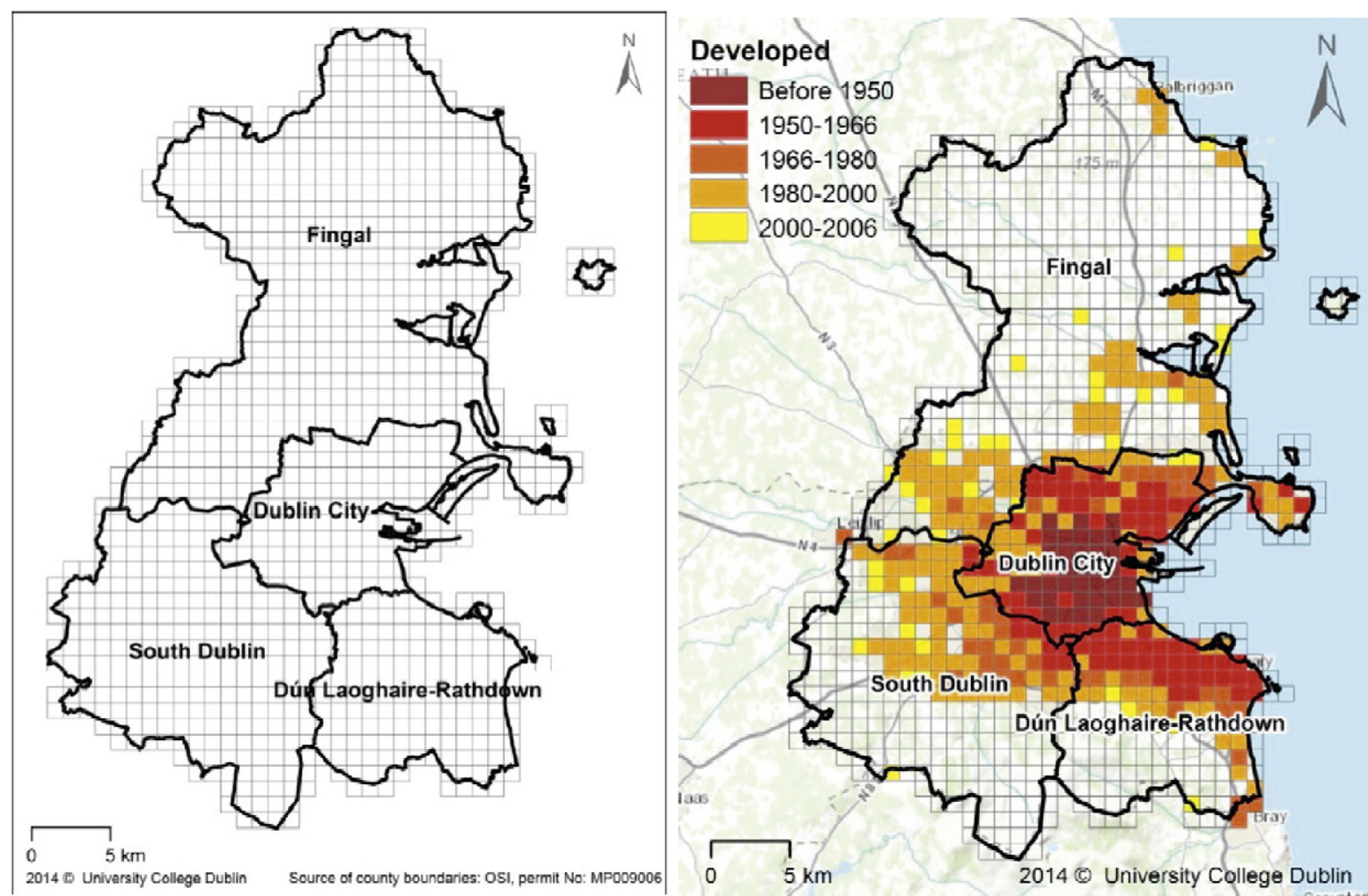

Bcforc 1950 - 36 cells; 1950-1966 - 85 cells; 1966-1980 - 51 cells; 1980-2000 - 165 cells; 2000-2006 - 40 cells

Fig. 2. Counties in Dublin Region under $1 \mathrm{~km} \times 1 \mathrm{~km}$ cell grid (left) and urban development over 5 time periods (right).

Irish cities and planning community to perhaps redress previous policy weaknesses.

\subsection{Base maps and data}

The sources of data used in this research are: Ordnance Survey Ireland for county boundaries and topographic maps; Tele Atlas 2006 for road network; AnPost (Irish Postal Service) GeoDirectory 2012 for residential and commercial addresses; Irish Environmental Protection Agency for CORINE 2000 and 2006 land cover data; Environmental Systems Research Institute (ESRI) for background maps; and Irish Central Statistics Office (CSO) for population data and census boundaries.

The unit of analysis is a neighbourhood, but in the absence of detailed parcel level data, as used in Knaap and Song's studies, the neighbourhoods are defined by $1 \mathrm{~km} \times 1 \mathrm{~km}$ grid cells (Fig. 2, left). For all cells covering Dublin Region a year of development is designated using CORINE land cover data and topographic maps. This is a crucial piece of information for examining changes in the nature of urban patterns over time. As an alternative to detailed individual parcel-level data with building construction dates, we estimate the development period for each cell. For each of $10891 \mathrm{~km} \times 1 \mathrm{~km}$ cells covering Dublin Region we assign one of the five development periods: before 1950 , 1950-1966, 1966-1980, 1980-2000 and 2000-2006 (Fig. 2 right). The time periods are selected by taking into consideration data availability for the region - including high quality topographic maps for 1950, 1966 and 1980 and satellite imagery-based CORINE land cover dataset for 2000 and 2006.

The logic used to assign time periods based on available data assumes that the form of urban development remains constant over subsequent time periods. For the periods before 1950, 19501966, and 1966-1980, we rely on topographic maps, which are scanned, geo-referenced and overlaid with the grid. Starting from the earliest map, if visual assessment indicates that urban development covers more than $50 \%$ of the cell area, the area is considered as developed for that and the following periods. For the periods 1980-2000 and 2000-2006 we use CORINE land cover data to identify cells with more than $50 \%$ of urban land cover and designate them as developed for that and the subsequent periods. About one third of the 1089 cells (377) are designated as developed during at least one of the five periods.

As Fig. 2 suggests, the pre-1950 development was confined to about $30-40 \mathrm{~km}^{2}$ of the traditional and compact city and the emerging modern city region following the wars and political upheavals of 1916 to 1922 (Bannon, 2004). In the period following the WWII the direction of both private developments and public housing programmes was firmly toward suburban development along radial routes from the city encompassing existing smaller settlements. The late 1950s commenced a period of industrial and economic development and a concomitant expansion of Dublin Region. This led to increased congestion and development pressures on central Dublin as more dispersed population became increasingly dependent on the private motor car as a means of transportation. From the 1960s residential developments were complemented with new suburban retail shopping centres with ample car parking and services, initially featuring food and later non-food retail sales and services. By mid 1960s, Dublin Region tripled in built environment surface area as over $80 \mathrm{~km}^{2}$ were added to its extent, mostly toward the south-east along the coast of the Irish Sea and less so to the north of the pre-1950s city. The 1970s saw only sporadic development on the fringes surrounding the existing built up areas toward north-east, south-west and further south-east. Considerable new growth was evident in the period between 1980 and 2006 which included the 'Celtic Tiger' years and related property boom in Ireland and the Dublin Region especially. 
The number of grid cells showing development in specific periods illustrates the substantial expansion of the city from the 1980s in particular. Out of total 377 cells assigned as developed, 36 or less than $10 \%$ were built from 1000 to $1950,{ }^{7}$ while the remainder $90 \%$ of the cells were developed in the past 50 years; of those, $60 \%$ (205 cells) was developed during the Celtic Tiger years. Physically, the five periods have produced distinct urban forms, which evolved in the context of the Dublin Region (Fig. 3).

\subsection{Measures}

The changes in Dublin's urban form between 1950 and 2006 are measured with five variables, adapted from Knaap et al. (2007) work, two of them related to street network design (internal and external connectivity), one related to land use mix, and two related to density (residential and commercial density). For each cell in Dublin Region five measures of urban form are computed using geographic information system (GIS) functions.

\subsubsection{Street network design}

Once developed, the street network becomes a long-term (possibly permanent) feature and a determinant of urban form and sprawl (Barrington-Leigh \& Millard-Ball, 2015). One of the consequences of urban sprawl is poor accessibility and lack of connectivity in suburban developments. Connectivity is an important indicator as better connectivity has been argued to lead to more walking and biking, fewer vehicle miles travelled, higher air quality, and greater sense of community among residents (Benfield, Raimi, \& Chen, 1999). We apply two measures of connectivity by overlaying and intersecting street network file and the boundaries of $1 \times 1 \mathrm{~km}$ grid:

- Internal Connectivity (Int_Connectivity) measures transportation route options within a neighbourhood (cell) as the sum of the number of sections intersecting within $1 \mathrm{~km}^{2}$ grid cell (Fig. 4 left). The higher the number, the greater the internal connectivity.

(Knaap et al.: ratio of the number of intersections and sum of culde-sacs (or dead ends) plus intersections).

- External Connectivity (Ext_Connectivity) measures route options between neighbourhoods (cells) as the number of intersections of roads with the boundary of each $1 \mathrm{~km}^{2}$ grid cell multiplied by two (because each road is divided into 2 sections after intersecting with a cell boundary; Fig. 4 right). The higher the number the greater the external connectivity. The external connectivity indicates how well a grid cell is connected with other cells. (Knaap et al.: median distance between neighbourhood ingress/ egress (access) points)

The calculations on the internal and external connectivity for Dublin Region in terms of density of interconnecting segments per $1 \mathrm{~km}^{2}$ show the highest values in Dublin's inner city and a decrease further away from the city centre (Fig. 5). The exceptions to this general pattern are occasional cells with high connectivity found scattered across Dublin Region. These represent existing urban villages in the region and pockets of new developments built adjacent to existing transport infrastructure and denser street network.

\subsubsection{Land use mix}

Studies in the U.S. (Burchell et al., 1998) and Europe (EEA, 2006) suggest that homogenisation of land uses is related to sprawl. Greater mixing of uses facilitates walking and biking, lowers vehicle miles travelled, improves air quality and enhances urban aesthetics (APA, 1998; EEA, 2006). Similarly, in the absence of land use mixing, residences

\footnotetext{
7 Based on our methodology, developed means more than 50\% of the cell was under built up area. It is possible that a number of cells less than half of their area was built up, and hence not counted as developed (although partially developed).
}

(often single-family homes in case of low density sprawl) are often located at great distances from commercial establishments, which further discourages walking and increases the dependence on the automobile (Galster et al., 2001). We apply the following measure of land use pattern:

- Land Use Mix (Landuse_Mix) is measured as the number of classes within the neighbourhood $(1 \times 1 \mathrm{~km}$ cell $)$ of artificial land covers represented by CORINE classes from 111 to 142 (Fig. 6): Continuous urban fabric, Discontinuous urban fabric, Industrial and commercial units, Road and rail network, Seaport, Airports, Mineral extraction sites, Dump, Construction Sites, Green urban areas, and Sports and leisure facilities (Knaap et al.: diversity index of land use classes within a neighbourhood)

\subsubsection{Density}

Density is the basic and probably most widely (internationally) used measure of urban structure and development pattern at regional (metropolitan) and local scales (Burton, 2000; Galster et al., 2001; Ewing et al., 2002; Jabareen, 2006). Also, it may be the most debatable indicator, given its dependency on the context, as well as other factors (e.g., connectivity). We employ two measures of density:

- Commercial Density (Com_Density) is measured as the number of commercial addresses in the neighbourhood (cell). The coordinates of commercial postal address points are overlaid with the neighbourhood grid to generate the density of such establishments per $1 \mathrm{~km}^{2}$. (Knaap et al.: median distance of neighbourhood parcel centroids to the nearest commercial use)

- Residential Density (Res_Density) is measured as the number of residential addresses in the neighbourhood (cell). The coordinates of residential postal address points are overlaid with neighbourhood grid to generate residential density per $1 \mathrm{~km}^{2}$. (Knaap et al.: medium lot size and medium floor area of single-family units within a neighbourhood)

As in the case of connectivity, Commercial Density and Residential Density are highest in Dublin's inner city (Fig. 7 left and middle). Residential density is derived by overlaying point data on postal addresses (GeoDirectory) over the $1 \mathrm{~km} \times 1 \mathrm{~km}$ grid. The mismatch between the census boundaries and $1 \mathrm{~km} \times 1 \mathrm{~km}$ grids prevent the use of census data. By using the addresses in form of point data, we assume that the number of residential addresses approximates the number of households and if multiplied with the average household size it would indirectly indicate the population size. The inaccuracies and disparities are suspected in cases when one address point in GeoDirectory represents multiple residences. This could lead to underestimations in the areas with substantial number of buildings with multiple units (e.g., in the central areas of Dublin). To check if the data based on residential addresses provide a valid measure of the residential density, we compare it to the density derived from population data (number of people per area) from 2011 Census at Small Area (SA) level. A visual comparison of the density map based on residential addresses in GeoDirectory (Fig. 7, middle) with the Census-based population density map (Fig. 7, right) affirms that the residential data from the two sources are comparable and that GeoDirectory represents a reliable source. We also confirm this by a statistical correlation between the total number of households obtained from Census data and the number of residential addresses in 4806 SAs (excluding 91 areas that had no population). The correlation 0.793 is statistically significant with a definite linear trend (Fig. 8).

Graphs representing the values for each of the 5 measures are enclosed in the Appendix A. 
Before 1950

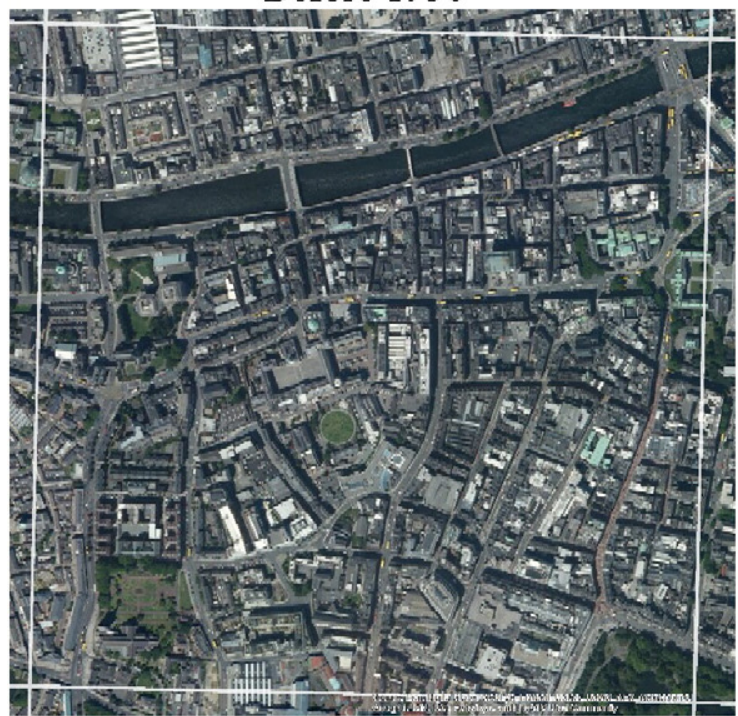

$1966-1980$

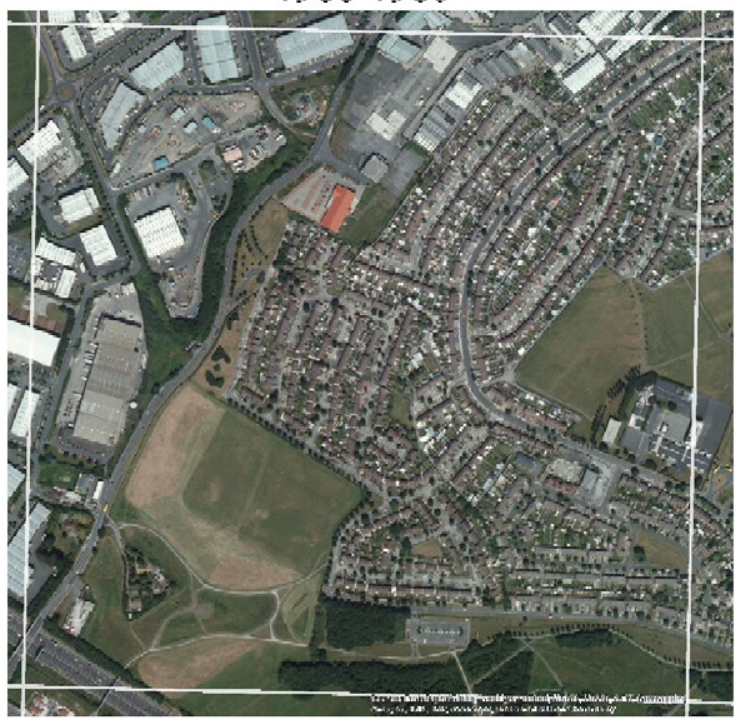

$1950-1966$

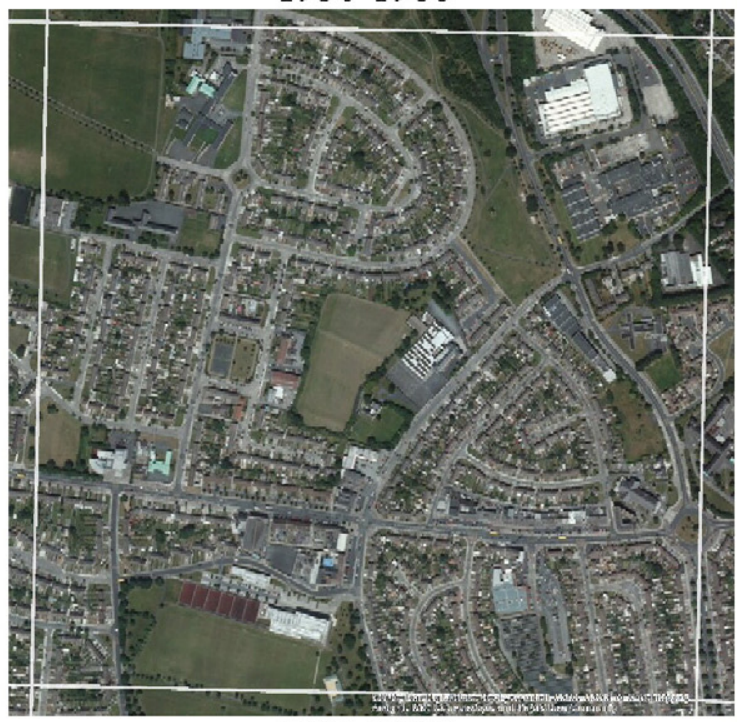

$1980-2000$

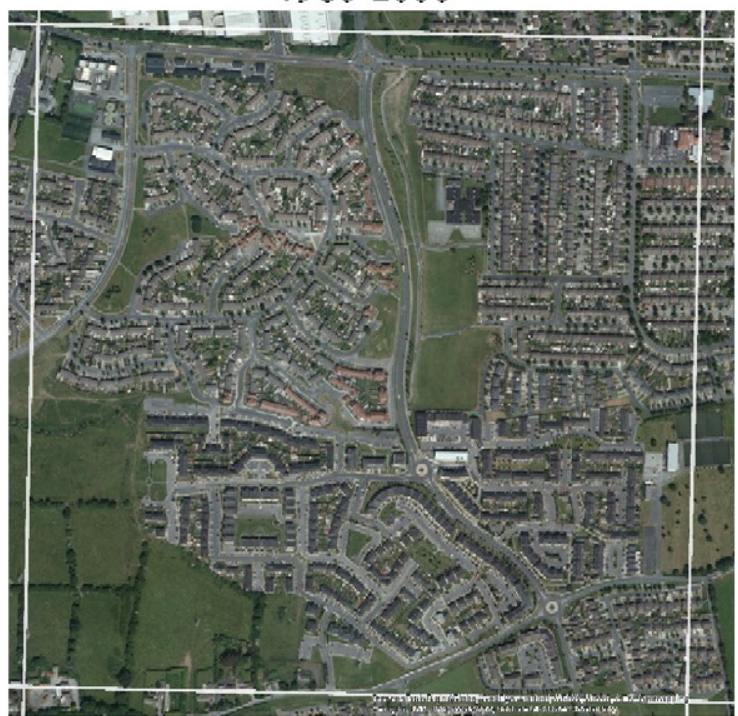

$2000-2006$

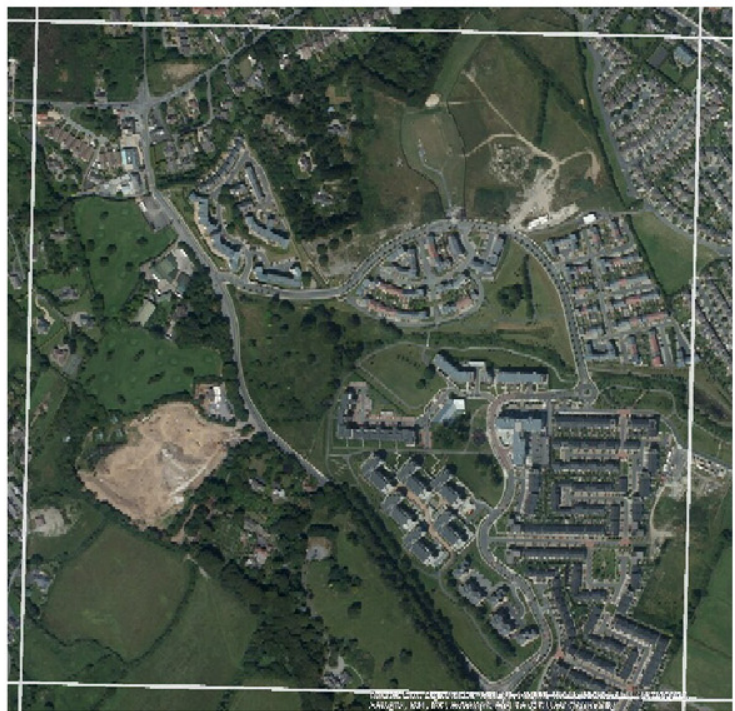

Fig. 3. Representative/sample urban forms in the Dublin Region over the five studied periods. (Source: ESRI, Digital Globe; white lines indicate grid cell boundaries). 


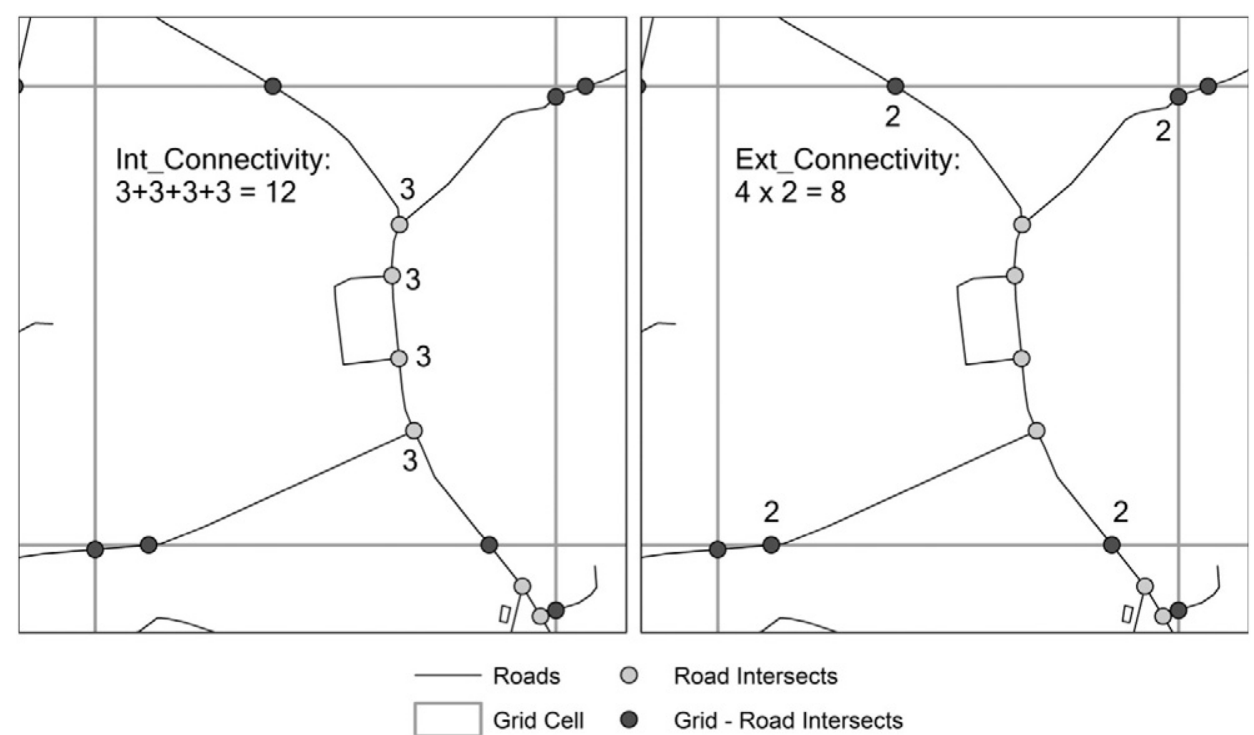

Fig. 4. Internal (left) and external (right) connectivity measures illustrated on a sample grid cell.

\subsection{Analysis}

The median values of each measure are compared to examine the differences in their values between the neighbourhoods grouped by their development period. For all measures except Commercial Density and Land Use Mix the assumption of normal distribution within groups required for ANOVA (Analysis of Variance) is rejected based on significance of Kolmogorov-Smirnov test (Appendix B). Therefore, the Kruskal-Wallis nonparametric test is used to assess for the significance of differences of those urban form measures (continuous dependent variable) between the five development periods (grouping independent variable). The Kruskal-Wallis test is a non-parametric counterpart of the one-way ANOVA test, and relevant for the cases when the ANOVA normality assumptions do not apply. It is a rank based method for testing whether samples originate from the same distribution (Marques de Sá, 2007). Similar shape of the boxplots in Fig. 9 indicates that the requirement of Kruskal-Wallis test of having the same shape of distributions in each group is satisfied for all measures except Land Use Mix. Therefore, Kruskal-Wallis test is applied for all measures except Land Use Mix. On the other hand, taking into account the results of the normality test, ANOVA is applied for Commercial Density and Land Use Mix.

ArcGIS 10.1 software is used for manipulation and analysis of geospatial data and as general data storage and integration tool. Statistical
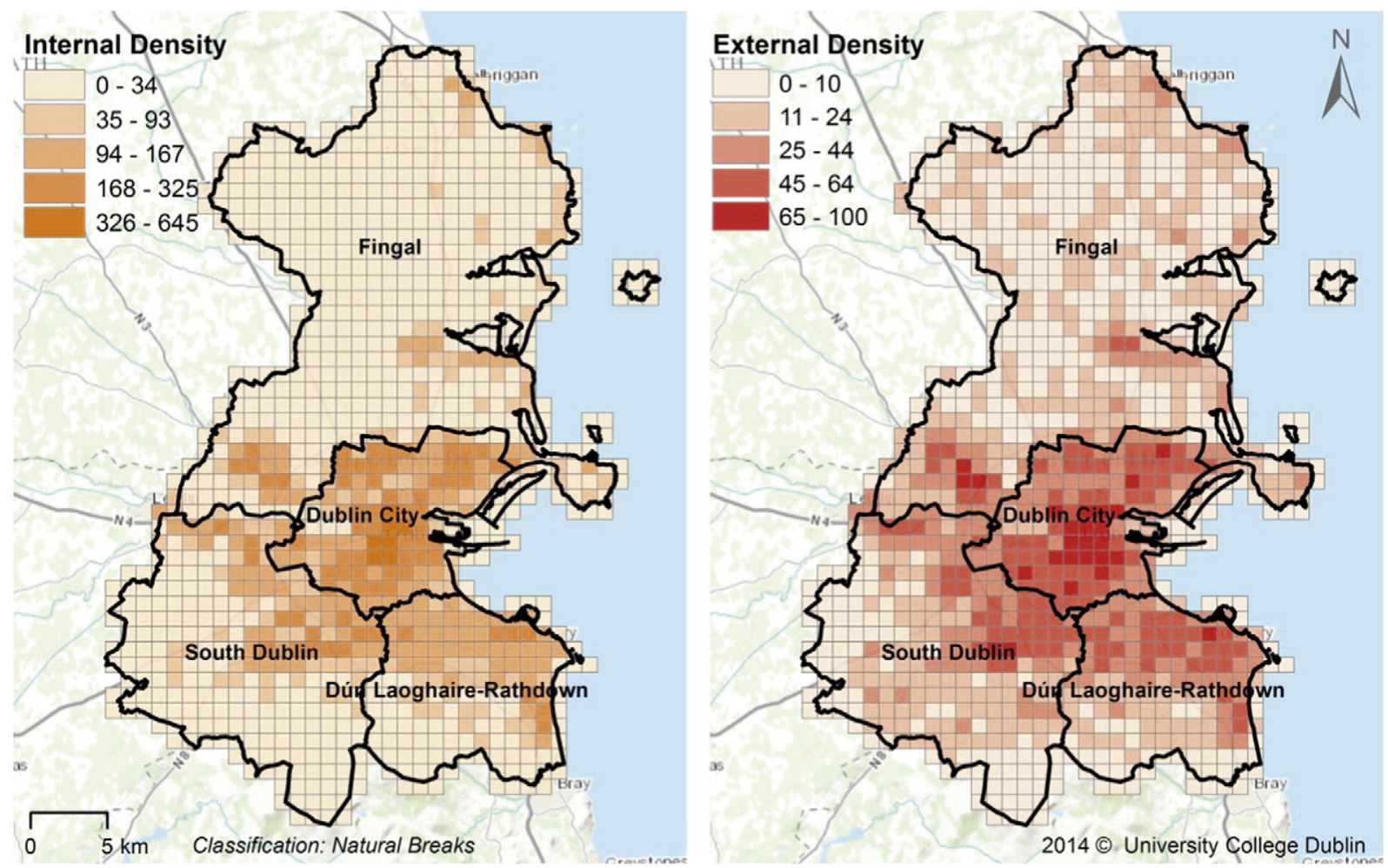

Fig. 5. Internal (left) and external (right) connectivity (density of road segments per $1 \mathrm{~km}^{2}$ ) for Dublin Region. 
CORINE Land Cover Classification (Level 3)

\begin{tabular}{|c|c|}
\hline 111 & Continuous urban fabric \\
\hline 112 & Discontinuous urban fabric \\
\hline 121 & Industrial and commercial units \\
\hline 122 & Road and rail network \\
\hline 123 & Sea ports \\
\hline 124 & Airports \\
\hline 131 & Mineral extraction sites \\
\hline 132 & Dump \\
\hline 133 & Construction sites \\
\hline 141 & Green urban areas \\
\hline 142 & Sport and leisure facilities \\
\hline 211 & Non-irrigated arable land \\
\hline 212 & Permanently irrigated land \\
\hline 213 & Rice fields \\
\hline 221 & Vineyards \\
\hline 222 & Fruit trees and berries plantations \\
\hline 223 & Olive groves \\
\hline 231 & Pastures \\
\hline 241 & Annual crops associated with permanent crops \\
\hline 242 & Complex cultivation patterns \\
\hline 243 & Land principally occupied by agriculture \\
\hline 244 & Agro-forestries \\
\hline
\end{tabular}

2014 (C) University College Dublin
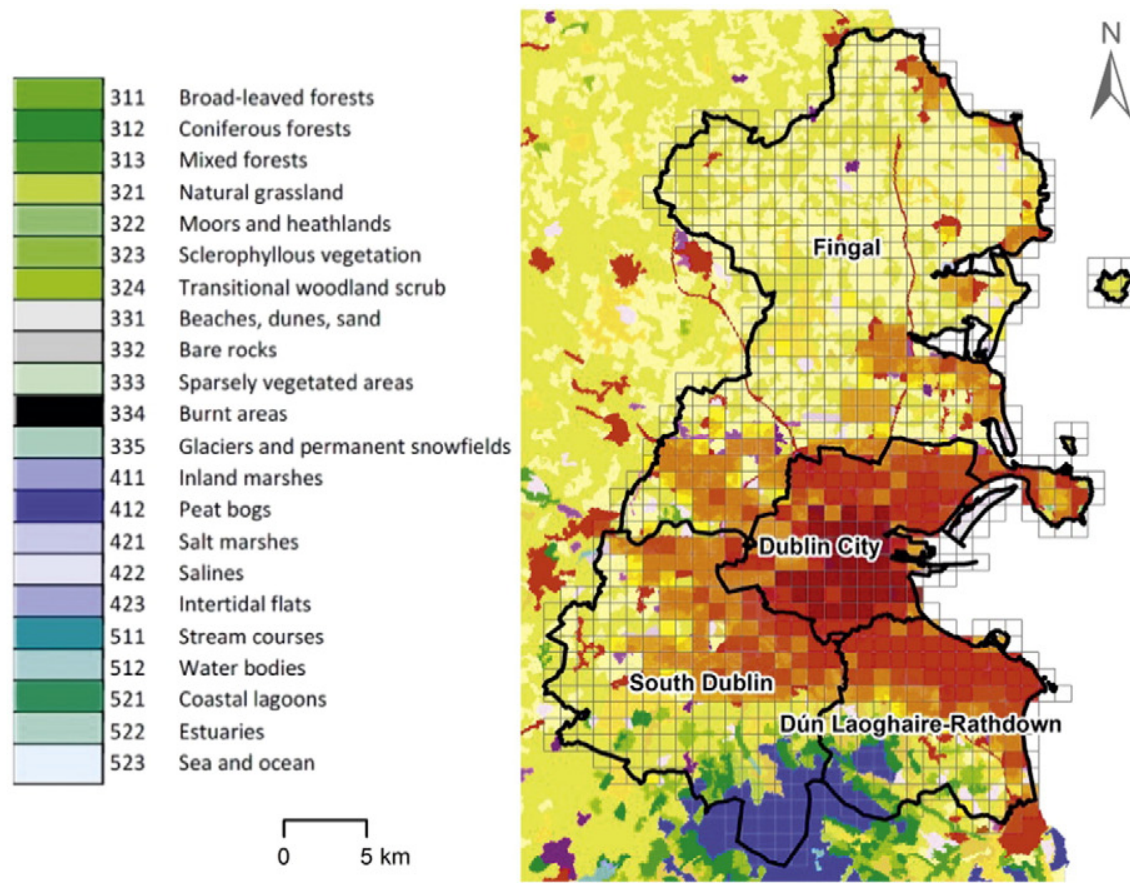

Fig. 6. Land use in Dublin Region. (Source: CORINE, 2006). package, SPSS 20, is used for statistical analysis of the change in values of the five measures between the five time periods and to test for significant differences.

\section{Results}

To analyse changes in development patterns over time, we first provide descriptive statistics of each measure for the five studied periods (Table 3). Except for the Land Use Mix, there is a general tendency of decrease of mean/median values of all indicators over the study period (Fig. 10), with the highest values observed for the neighbourhoods (cells) developed before 1950 and the lowest values for the areas developed between 2000 and 2006. The mean of Land
Use Mix measure is relatively stable with lowest observed value of 1.68 for the neighbourhoods developed in the period of 1950-1966, and the highest value of 2.31 for the areas developed in the period of 1980-2000.

In general the trends in Internal Connectivity and External Connectivity are similar. Both measures have their highest median in the areas developed before 1950s, which covers mainly the Dublin city centre. Both connectivity measures decrease over time as development moves from the centre toward the periphery. However, Internal Connectivity falls much more rapidly with the mean value of areas developed between 2000 and 2006 falling 13 fold compared with the areas developed before 1950; for the same period External Connectivity fell 'only' by 4 fold. The data point to a significant departure from the
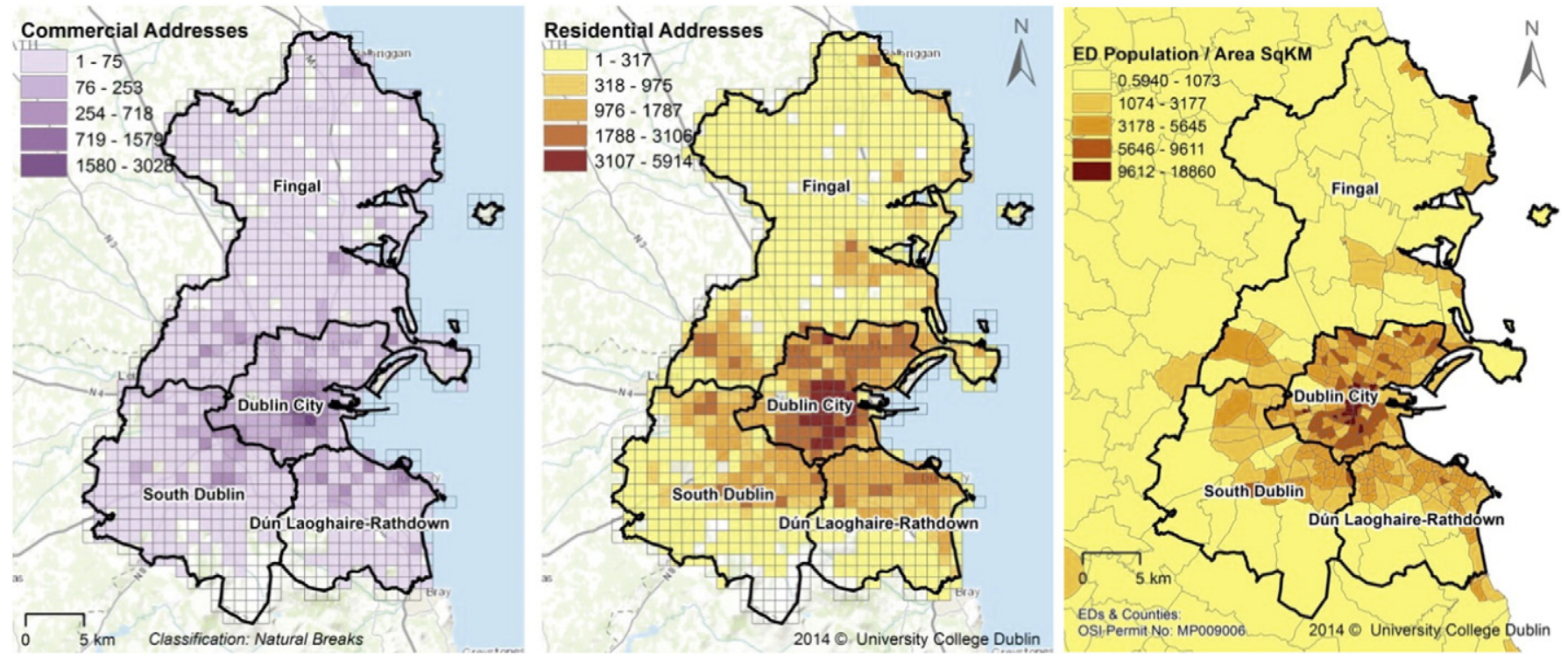

Fig. 7. Density of commercial addresses (left) and residential addresses (middle) per $1 \mathrm{~km}^{2}$ grid cell and population density based on Census data (right). 


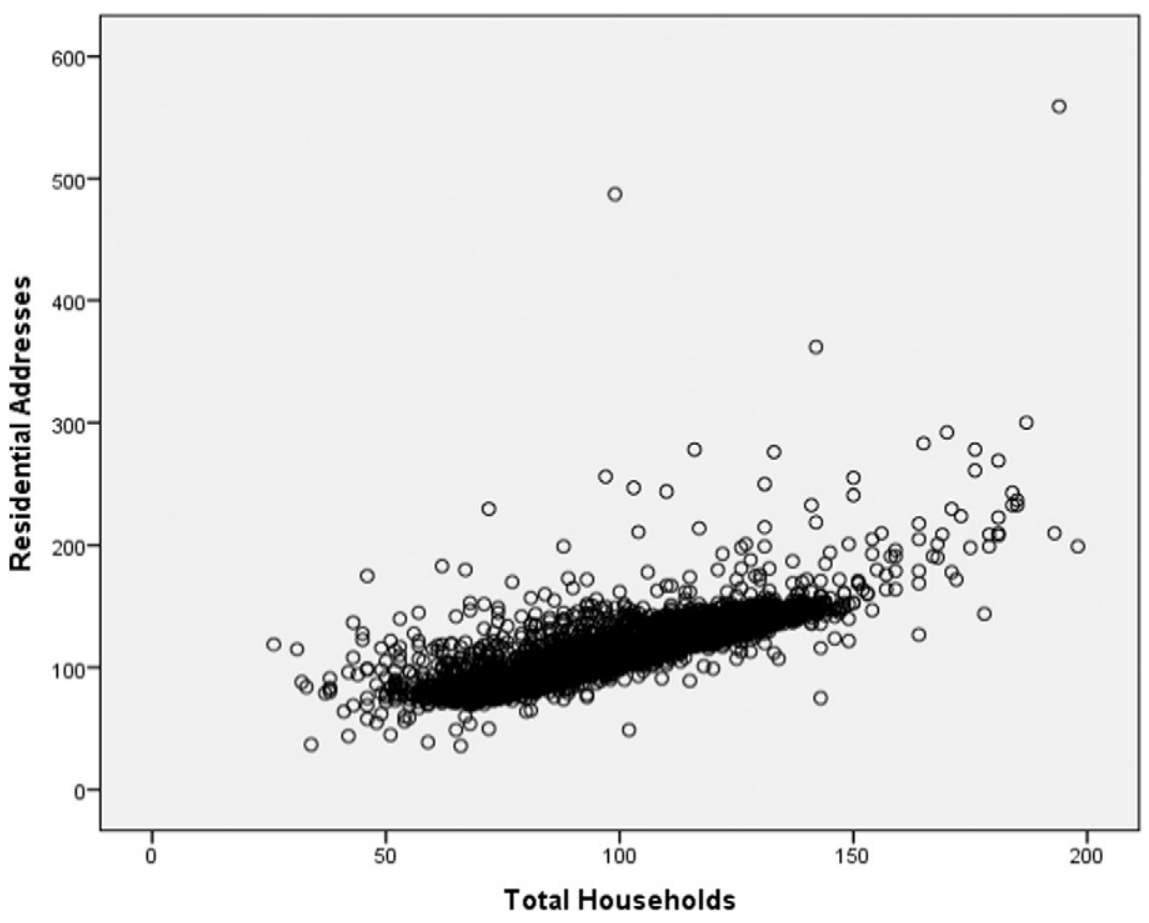

Fig. 8. Scatterplot showing correlation between the number of residential addresses and the number of households at Small Areas level in Dublin Region.

traditional urban form with dense street network and related accessibility and mobility within the neighbourhood but also increasingly limited connectivity with the surrounding areas.

With regard to the measures of Commercial Density and Residential Density we observe a similar tendency, with the highest median values in the areas developed before 1950 and the lowest in the areas developed between 2000 and 2006. During this period the mean value of Commercial Density fell by a factor of 11 , while the Residential Density fell by a factor of 5 , indicating a possible under-provision of services in the more recently developed areas. This could also be related to the proliferation of larger commercial centres, which may be replacing the traditional small-scale shopping centres which are locally oriented and more dispersed through residential communities.

The trend is different for the Land Use Mix measure, which is quite stable across the time periods. The median value of Land Use Mix is the same for all covered periods and equals to 2 . However, the mean values show a significant drop in the period 1950-1966, 1980-2000, and 2000-2006. Interestingly, in the comparative study of five counties in the U.S. by Knaap et al. (2007), land use mix also shows no clear pattern across the cases and no apparent temporal trend. This is particularly interesting since the U.S. authors use a much different measure of land use mix and larger geographic units. This suggests a robustness that is worth exploring in future research and in other metropolitan areas.

The results of ANOVA and Kruskal-Wallis tests supports a conclusion that there is a statistically significant (at $\mathrm{p}=0.000$ level) difference in the median (for all measures except Land Use mix) and/or mean (Commercial Density and Land Use Mix) values among the five development periods for all studied measures of urban form (Table 4).

However, ANOVA and Kruskal-Wallis test only confirm that differences exists; they do not identify where the differences are. The pairwise comparisons of medians and distributions for the five measures of urban form between each two periods shows that, except for Land Use Mix, all studied indicators have different median and/or distribution between the period before 1950 and 1950-1966 (Table 5). This is the first significant turn in the way of Dublin's growth and a departure from the traditional form. On the contrary, between 1950-1966 and 1966-1980 periods, all indicators, including Landuse Mix, have similar medians and distributions, meaning no major change in the built form.
This along with the comprehensive shift in almost all indicators in the following pairwise periods (1966-1980 and 1980-2000) suggests that the considerable change in the design and construction of urban areas happens again from 1980 on. Between the final pair of periods (1980-2000 and 2000-2006), the connectivities are further differentiated, and also the commercial developments start to depart more from the extent and pattern exhibited in the preceding periods. This is also observable from the boxplots of the measures presented in Fig. 9 above.

\section{Discussion and conclusion: measuring urban form to inform local planning}

Methodological perspectives for characterising urban forms are wide ranging to include: landscape ecology, economic structure, transportation planning, community design, and urban design (Clifton et al., 2008). The definitions of what is urban form are as varied and conceptually linked to connectivity, land use, density, distribution, contiguity, and shape of the built environment. The various characteristics of urban form are measured either individually or combined as indexes or coefficients and with a range of methods and at various scales - regional (metropolitan), city, and community (Tsai, 2005). With no agreed upon definition, the manifestations of various forms, sprawl in particular, have been studied extensively, particularly at the metropolitan and citywide scale. Numerous studies and debates are published on the nature, extent and impact of sprawl, using the examples of metropolitan areas in the United States in particular and less so of European cities and urban regions (Hamidi \& Ewing, 2014). The studies at community scale are particularly rare in the European context and the research presented in this paper focuses at that particular scale.

A review of measures of urban form at the community scale converges to five indicators: density, land use mix, connectivity, accessibility, and ecological design. The most comprehensive empirical application of these measures is by Knaap et al. (2007) and Song and Knaap (2004), whose work we replicate to examine three of these indicators. We study the evolution of urban form of Dublin Region in Ireland by employing the measures of External Connectivity and Internal Connectivity, Land Use Mix, and Residential Density and Commercial Density. Our findings show a clear and statistically significant differentiation 

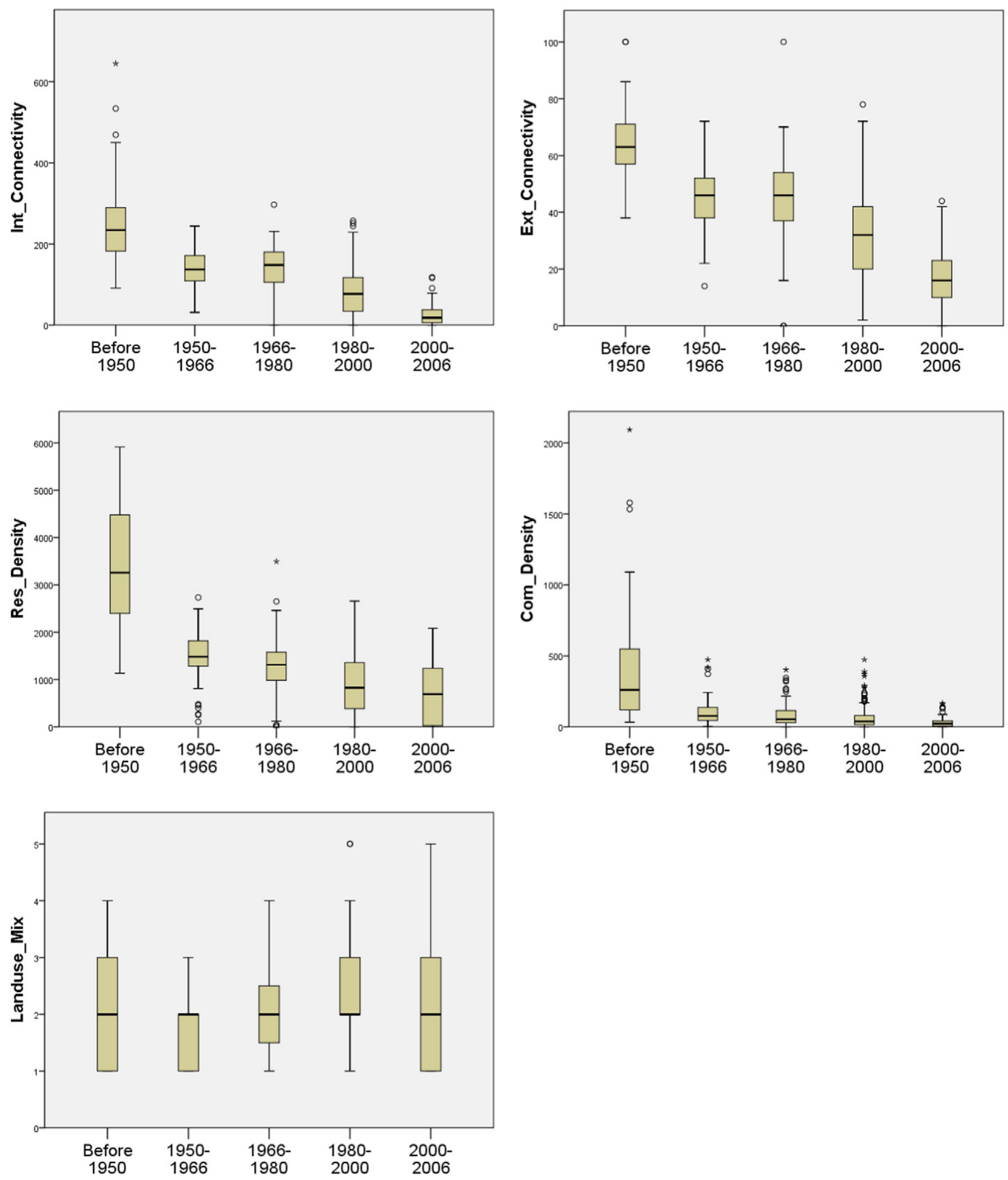

Fig. 9. Boxplots of the five urban form measures by period of development.

between urban forms established during the five periods covered in the study. They also confirm a trend toward suburban and low density urban form on all indicators, except for Land Use Mix. While it is not the purpose of this research effort to demarcate at which point a particular peripheral urban growth and its respective form qualify as sprawl, qualitatively, the revealed direction of change that the urban development exhibits over time in Dublin Region is clear. The areas developed in the period 2000-2006 have the lowest average Internal Connectivity and External Connectivity and Residential Density and Commercial Density. Even without measuring their fragmentation or patching, the developments of this period appear dispersed and dependent on car-based transport. 
Table 3

Descriptive statistics of the measures.

\begin{tabular}{|c|c|c|c|c|c|c|c|c|c|}
\hline & & \multirow[t]{2}{*}{$\mathrm{N}$} & \multirow[t]{2}{*}{ Mean } & \multirow[t]{2}{*}{ Std. deviation } & \multirow[t]{2}{*}{ Std. error } & \multicolumn{2}{|c|}{ 95\% Confidence interval for mean } & \multirow[t]{2}{*}{ Min } & \multirow[t]{2}{*}{ Max } \\
\hline & & & & & & Lower bound & Upper bound & & \\
\hline \multirow[t]{6}{*}{ Int_Connectivity } & Before 1950 & 36 & 259.58 & 120.167 & 20.028 & 218.92 & 300.24 & 91 & 645 \\
\hline & 1950-1966 & 85 & 138.14 & 44.913 & 4.872 & 128.45 & 147.83 & 31 & 244 \\
\hline & 1966-1980 & 51 & 137.39 & 64.504 & 9.032 & 119.25 & 155.53 & 0 & 297 \\
\hline & $1980-2000$ & 165 & 82.32 & 57.520 & 4.478 & 73.48 & 91.16 & 0 & 257 \\
\hline & 2000-2006 & 40 & 29.65 & 30.723 & 4.858 & 19.82 & 39.48 & 0 & 118 \\
\hline & Total & 377 & 113.69 & 85.566 & 4.407 & 105.03 & 122.36 & 0 & 645 \\
\hline \multirow[t]{6}{*}{ Ext_Connectivity } & Before 1950 & 36 & 64.78 & 14.535 & 2.422 & 59.86 & 69.70 & 38 & 100 \\
\hline & 1950-1966 & 85 & 45.11 & 12.128 & 1.315 & 42.49 & 47.72 & 14 & 72 \\
\hline & 1966-1980 & 51 & 45.22 & 17.942 & 2.512 & 40.17 & 50.26 & 0 & 100 \\
\hline & 1980-2000 & 165 & 32.01 & 14.479 & 1.127 & 29.79 & 34.24 & 2 & 78 \\
\hline & 2000-2006 & 40 & 17.50 & 9.982 & 1.578 & 14.31 & 20.69 & 0 & 44 \\
\hline & Total & 377 & 38.34 & 18.562 & .956 & 36.46 & 40.22 & 0 & 100 \\
\hline \multirow[t]{6}{*}{ Com_Density } & Before 1950 & 36 & 507.39 & 648.167 & 108.028 & 288.08 & 726.70 & 33 & 3028 \\
\hline & 1950-1966 & 85 & 107.13 & 92.812 & 10.067 & 87.11 & 127.15 & 2 & 474 \\
\hline & 1966-1980 & 51 & 97.84 & 102.253 & 14.318 & 69.08 & 126.60 & 0 & 402 \\
\hline & $1980-2000$ & 165 & 65.27 & 80.326 & 6.253 & 52.93 & 77.62 & 0 & 474 \\
\hline & 2000-2006 & 40 & 37.30 & 44.889 & 7.098 & 22.94 & 51.66 & 0 & 167 \\
\hline & Total & 377 & 118.37 & 248.911 & 12.820 & 93.16 & 143.57 & 0 & 3028 \\
\hline \multirow[t]{6}{*}{ Res_Density } & Before 1950 & 36 & 3467.86 & 1309.229 & 218.205 & 3024.88 & 3910.84 & 1133 & 5914 \\
\hline & 1950-1966 & 85 & 1498.00 & 509.339 & 55.246 & 1388.14 & 1607.86 & 106 & 2735 \\
\hline & 1966-1980 & 51 & 1284.75 & 718.381 & 100.593 & 1082.70 & 1486.79 & 1 & 3498 \\
\hline & 1980-2000 & 165 & 894.48 & 674.354 & 52.498 & 790.82 & 998.14 & 0 & 2658 \\
\hline & 2000-2006 & 40 & 703.83 & 646.841 & 102.274 & 496.96 & 910.69 & 3 & 2083 \\
\hline & Total & 377 & 1308.85 & 1047.206 & 53.934 & 1202.80 & 1414.90 & 0 & 5914 \\
\hline \multirow[t]{6}{*}{ Landuse_Mix } & Before 1950 & 36 & 2.00 & 0.926 & 0.154 & 1.69 & 2.31 & 1 & 4 \\
\hline & 1950-1966 & 85 & 1.68 & 0.658 & 0.071 & 1.54 & 1.82 & 1 & 3 \\
\hline & 1966-1980 & 51 & 2.02 & 0.761 & 0.107 & 1.81 & 2.23 & 1 & 4 \\
\hline & 1980-2000 & 165 & 2.31 & 0.960 & 0.075 & 2.16 & 2.46 & 1 & 5 \\
\hline & $2000-2006$ & 40 & 2.07 & 0.917 & 0.145 & 1.78 & 2.37 & 1 & 5 \\
\hline & Total & 377 & 2.07 & 0.896 & 0.046 & 1.98 & 2.17 & 1 & 5 \\
\hline
\end{tabular}
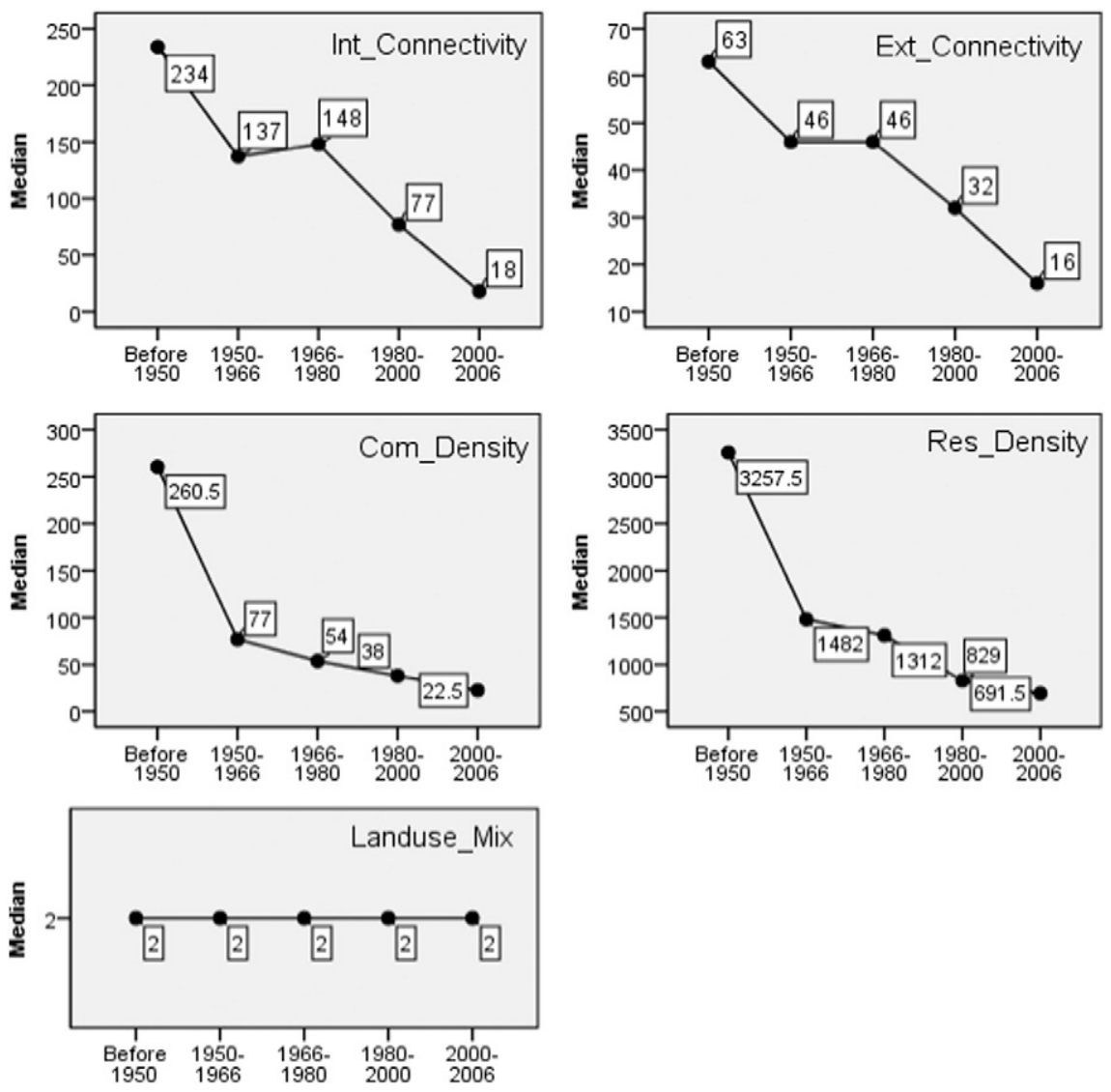

Fig. 10. Median values of five urban form measures over time. 
Table 4

Hypothesis test summary output of the statistical significance in the differences in median (Kruskal-Wallis Test) or mean (ANOVA) values of urban form measures.

\begin{tabular}{lllll}
\hline & $\begin{array}{l}\text { ANOVA test } \\
\text { (F) }\end{array}$ & $\begin{array}{l}\text { Kruskal-Wallis test } \\
\text { (chi-square) }\end{array}$ & Df & p-Value \\
\hline Int_Connectivity & N/A & 168.899 & 4 & 0.000 \\
Ext_Connectivity & N/A & 159.328 & 4 & 0.000 \\
Res_Density & N/A & 135.307 & 4 & 0.000 \\
Com_Density & 33.790 & 92.681 & 4 & 0.000 \\
Landuse_Mix & 7.491 & N/A & 4 & 0.000 \\
\hline
\end{tabular}

The community-based measures offer further insight. The fluctuations in values of indicators between the periods could be related to particular policies, initiatives or developments. For example, both the change in median values and the pairwise comparisons of all measures between each two periods (not only subsequent) point to the first significant expansion of Dublin from 1950 to 1966. Starting with the post-WWII economic revival, the Dublin Region started to grow with very little foresight and coordination. By 1960 the problems of uncontrolled development led the Irish government to seek the United Nation's technical advice on how to cope with problems related to Dublin's urban expansion (MacLaran, 1984). Dublin's twin problems of uncontrolled peripheral expansion and inner city decay were recognised as requiring corrective action and legislation leading to the introduction of the modern statutory planning system in 1964 (Abrams, 1961).

With respect to Residential Density and Commercial Density, the pairwise analysis helps us trace the mutual dynamics. The data suggest that the significant lowering of the Commercial Density is associated with the most recent period (2000-2006 in our study), while the lowering in the Residential Density dates to pre-2000 period (1980 to 2000 in our study). Indeed the observed reality corresponds to what the data tells. After some relatively quiet period, which included the economic crisis of the 1980s, what followed was another development boom in parallel with the Celtic Tiger period from mid 1990s to 2008 (2006 being the final year captured in this study). Interestingly, the EEA (2006) suggested that sprawl has been particularly evident where countries or regions have benefited from EU regional policies and Ireland was among those countries which received substantial European structural funds. During this period, the 2000 Planning and Development Act was in force, but clearly undermined by the corruption-ridden local political process, overzoning, and speculative development fuelled by easy access to vast amounts of credit (Williams et al., 2010; Williams, 2011; Williams \& Boyle, 2012; Grist, 2011, 2012; Fox-Rogers, Murphy, \& Grist, 2011). In addition to the legislative framework, in this period the National Spatial Strategy (NSS, 2002) was adopted to provide for a coherent and balanced urban, rural and regional development. However, in general, the development decisions and patterns differed substantially from policy stated in the NSS and from international best practise as represented by the 1999 European Spatial Development Perspective (Grist, 2015; Cussen, 2015).

The dissimilar rate of fall between the Internal Connectivity and External Connectivity also corresponds to the on-the-ground developments. While the former decreases more than tenfold, the latter drops about fourfold. This difference could be related to the established (or lacking) local and national policies and frameworks for guiding the Region's development, with regard to improvements in primary and secondary road infrastructure. From 1980s at the national level there was a concerted effort to provide spatially connective infrastructure, mostly in form of motorways between Dublin and other major cities in the southwest, west and north Ireland, in addition to Dublin's M50 ring road. Such planned infrastructure was vital for managing the development of growing urban areas, but a singular focus on improved transportation exercised during this period failed to recognise the major linkages between transport provisions, urban development and settlement patterns in a period of rapid economic and population growth. While the new suburban (and rural) development was enabled by the provision of major infrastructure, less attention was paid to design of local street network in the new communities.

Land Use Mix is the only measure to exhibit a different behaviour from others. Its median is stable across the periods, and the general finding is consistent with Knaap et al. (2007) findings of no clear temporal or geographic pattern. However, the mean value decreases in the same periods when the major low density suburban expansion happens around Dublin, namely 1950-1966, 1980-2000, and 2000-2006. While the trend in means makes substantive sense, the results on Land Use Mix, in our view, might be indicative of a broader issue of obtaining adequate data for analysing urban form at the community scale. It is encouraging that a similar result is achieved with two very different measures of Land Use Mix at varied geographic scales. However, CORINE land cover data is a course substitution for more detailed local land use information. Knowing and experiencing the diversity of Dublin's central area (pre-1950 development), is hard to accept the average scores equated with the subsequent periods. By its nature, CORINE's data capture is two-dimensional and limited to designating the visible land covers. Hence, the many ground floor commercial establishments could be categorised as continuous or discontinuous urban fabric instead of commercial land cover. Even if vertical land use information were available, methodologically, it would be difficult to compose a measure that takes into account multiple land uses stacked on top of one another.

A wider and more significant data-related issue is one of resolution. Our study exhibits considerable creativity in using the available datasets and developing procedures to assess urban form at a local community (neighbourhood) scale. While Knaap et al. (2007) take a full advantage

Table 5

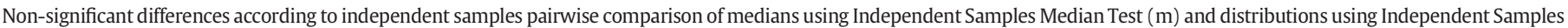
Kruskal-Wallis test (d).

\begin{tabular}{|c|c|c|c|c|c|}
\hline & Before 1950 & 1950-1966 & 1966-1980 & $1980-2000$ & $2000-2006$ \\
\hline Before 1950 & & Landuse_Mix $^{\mathrm{d}}$ & Landuse_Mix ${ }^{\text {md }}$ & Landuse_Mix ${ }^{\text {md }}$ & Landuse_Mix $^{\text {md }}$ \\
\hline 1950-1966 & Landuse_Mix ${ }^{\mathrm{d}}$ & & $\begin{array}{l}\text { Ext_Connectivity }{ }^{\mathrm{md}} \\
\text { Int_Connectivity }^{\mathrm{md}} \\
\text { Res_Density }^{\mathrm{m}} \\
\text { Com_Density } \\
\text { Landuse Mix }^{\mathrm{md}}\end{array}$ & Landuse Mix ${ }^{\mathrm{md}}$ & Landuse Mix ${ }^{\mathrm{md}}$ \\
\hline 1966-1980 & Landuse_Mix ${ }^{\mathrm{md}}$ & $\begin{array}{l}\text { Ext_Connectivity }{ }^{\mathrm{md}} \\
\text { Int_Connectivity }^{\mathrm{md}} \\
\text { Res_Density }^{\mathrm{m}} \\
\text { Com_Density }^{\mathrm{md}} \\
\text { Landuse_Mix }^{\mathrm{md}}\end{array}$ & & $\begin{array}{l}\text { Com_Density } \\
\text { Landuse_Mix }^{\mathrm{md}}\end{array}$ & Landuse_Mix ${ }^{\mathrm{md}}$ \\
\hline 1980-2000 & Landuse_Mix ${ }^{\text {md }}$ & Landuse_Mix ${ }^{\mathrm{md}}$ & $\begin{array}{l}\text { Com_Density } \\
\text { Landuse_Mix }^{\mathrm{md}}\end{array}$ & & $\begin{array}{l}\text { Res_Density } \\
\text { Landuse_Mix }^{\text {md }}\end{array}$ \\
\hline 2000-2006 & Landuse_Mix ${ }^{\mathrm{md}}$ & Landuse Mix ${ }^{\mathrm{md}}$ & Landuse_Mix ${ }^{\mathrm{md}}$ & $\begin{array}{l}\text { Res_Density }{ }^{\mathrm{md}} \\
\text { Landuse_Mix }^{\mathrm{md}}\end{array}$ & \\
\hline
\end{tabular}


of parcel-level datasets, our replication is mostly based on the national institutional datasets. In addition to low spatial resolution, the institutional datasets tend to be of a low temporal resolution, as their data collection and release adheres to particular time intervals. In our case study, the intervals are chosen primarily based on data availability and for the most part it worked. Starting the third period from 1966 is reasonable given the immediately preceding introduction of the Irish planning law. However, 1980 to 2000 is a long time span that includes two different phases in Irish socio-economic development - the crisis in the 1980s and the boom that gains momentum from mid 1990s. Conversely, the period 2000-2006 is quite short and determined by the availability of land cover data. An operational database that is developed as the events evolve, e.g., the properties are registered and transferred, or the buildings are constructed, offers a more potent spatial and temporal stamp. The scarcity of studies at the community level, especially in the European context, may be due to the reasons related to data deficiencies. The fact that very few cities would have such detailed databases on a variety of urban features, might prevent engagement in the national and comparative explorations.

In conclusion, we suggest that measuring the nature, extent and impact of urban growth at community scale is of critical importance for European urban policy to confront the challenges of low density developments. Newly available data, tools, and indicators enable planners and policy makers to understand those challenges better, make informed decisions, and anticipate the effects of interventions in urban regions. Even more fundamentally, it is necessary to distinguish urban sprawl from alternative urban forms (usually referred to as compact) in terms of particular physical manifestations (Tsai, 2005; Schwarz,
2010). This would allow planners to counter peripheral sprawl and promote high quality and efficient urban development with more specific regulatory, performance and incentive-based tools.

Finally, dependent on the availability of fine grain data and in its own right, we want to turn the attention to the relationship between the scale at which the nature of urban form is measured and understood and the policies devised to deal with urban development. Moving from the metropolitan to city and community scale, we suggest that corresponding policies and planning approaches are focused on general growth control and management (e.g., green belts, urban growth boundary, infrastructure provision), master (comprehensive) planning and zoning; and neighbourhood level (community) planning and design, respectively. Further research on the relationship between varying urban forms and policies and regulations that facilitate them should give better insight into matching the control and guidance mechanisms with particular outcomes.

\section{Acknowledgements}

The authors thank Jing Ran, Aisha Faiz, Susan Fogherty, Alan Crawford, Sarah Kerley and Maeve Mac Fadden for their assistance in data collection and preparation.

The work was partially supported by a Marie Curie International Outgoing Fellowship (GeoSInPo) within the European Commission Seventh Framework Programme and the European Commission FP7ENV.2011.2.1.5-1 (TURAS) Project Grant Agreement no. 282834.

\section{Appendix A. Spatial patterns and values of the measures of Internal and External Connectivity, Land use Mix and Residential and Commercial Density}
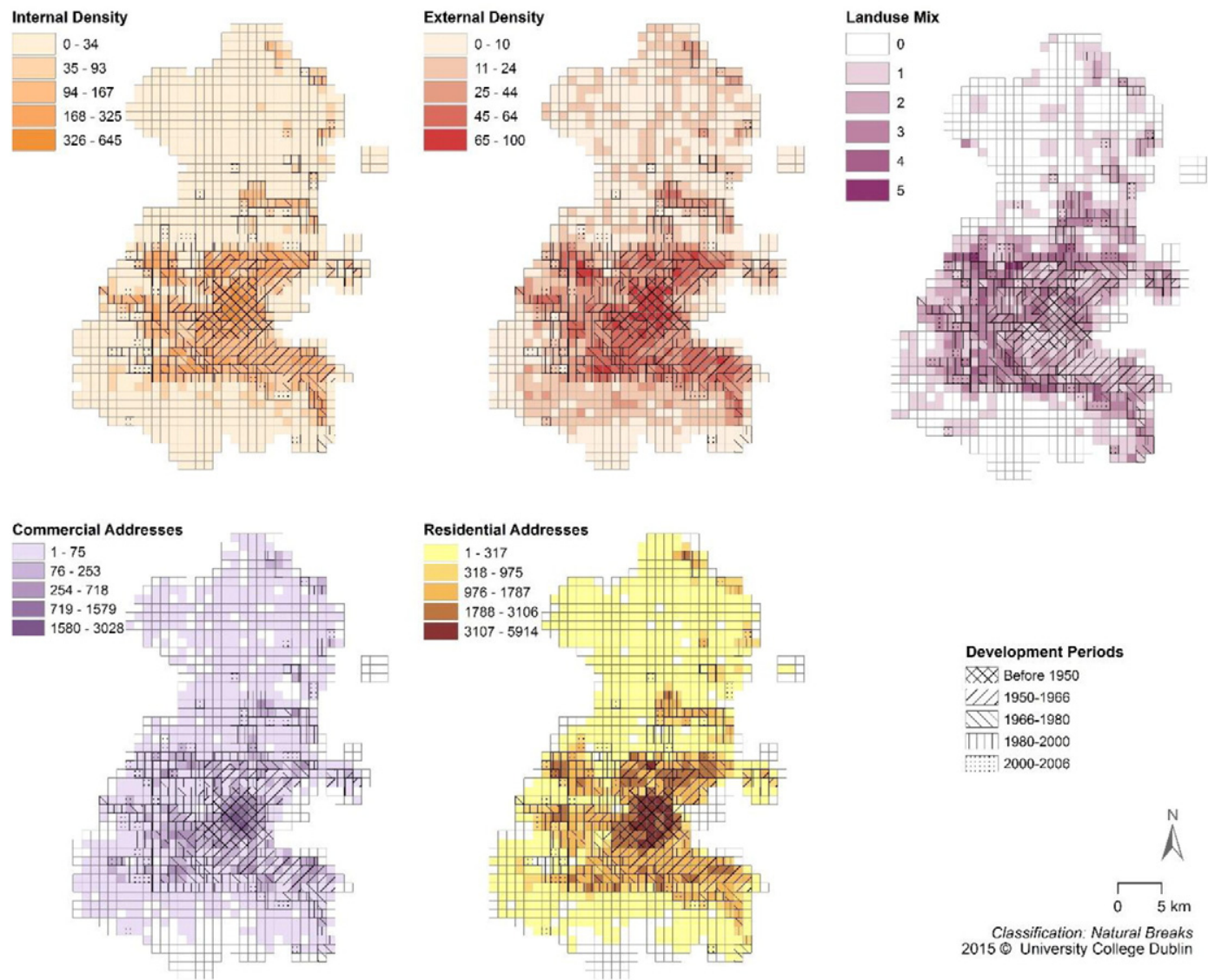


\section{Appendix B. Tests of normality within groups by period of development}

\begin{tabular}{|c|c|c|c|c|}
\hline & & \multicolumn{3}{|c|}{ Kolmogorov-Smirnov ${ }^{\mathrm{a}}$} \\
\hline & & Statistic & Df & Sig. \\
\hline \multirow{5}{*}{ Int_Connectivity } & Before 1950 & .194 & 36 & .001 \\
\hline & $1950-1966$ & .060 & 85 & $.200^{\mathrm{b}}$ \\
\hline & 1966-1980 & .092 & 51 & $.200^{\mathrm{b}}$ \\
\hline & $1980-2000$ & .076 & 165 & .021 \\
\hline & $2000-2006$ & .211 & 40 & .000 \\
\hline \multirow[t]{5}{*}{ Ext_Connectivity } & Before 1950 & .110 & 36 & $.200^{\mathrm{b}}$ \\
\hline & $1950-1966$ & .077 & 85 & $.200^{\mathrm{b}}$ \\
\hline & 1966-1980 & .127 & 51 & .038 \\
\hline & $1980-2000$ & .058 & 165 & $.200^{\mathrm{b}}$ \\
\hline & $2000-2006$ & .110 & 40 & $.200^{\mathrm{b}}$ \\
\hline \multirow{5}{*}{ Com_Density } & Before 1950 & .271 & 36 & .000 \\
\hline & 1950-1966 & .153 & 85 & .000 \\
\hline & 1966-1980 & .232 & 51 & .000 \\
\hline & $1980-2000$ & .235 & 165 & .000 \\
\hline & $2000-2006$ & .224 & 40 & .000 \\
\hline \multirow[t]{5}{*}{ Res_Density } & Before 1950 & .122 & 36 & .197 \\
\hline & 1950-1966 & .095 & 85 & .054 \\
\hline & 1966-1980 & .110 & 51 & .171 \\
\hline & $1980-2000$ & .092 & 165 & .002 \\
\hline & 2000-2006 & .177 & 40 & .003 \\
\hline \multirow[t]{5}{*}{ Landuse_Mix } & Before 1950 & .221 & 36 & .000 \\
\hline & 1950-1966 & .273 & 85 & .000 \\
\hline & 1966-1980 & .255 & 51 & .000 \\
\hline & $1980-2000$ & .244 & 165 & .000 \\
\hline & $2000-2006$ & .258 & 40 & .000 \\
\hline
\end{tabular}

${ }^{a}$ Lilliefors Significance Correction

b This is the lower bound of the true significance.

\section{Appendix C. Supplementary data}

Supplementary data associated with this article can be found in the online version, at http://dx.doi.org/10.1016/j.cities.2016.02.014. These data include the Google maps of the most important areas described in this article.

\section{References}

Abrams, C. (1961). Urban renewal project in Ireland (Dublin). United Nations programme for technical assistance. New York: United Nations.

American Planning Association (APA) (1998). The principles of smart development. Chicago: American Planning Association.

Antrop, M. (2004). Landscape change and the urbanization process in Europe. Landscape and Urban Planning, 67(1-4), 9-26.

Bannon, M. (2004). Irish urbanisation: Trends, actions and policy challenges. Planning and Environmental Policy Research Series, Working Paper No. 04/03. Dublin: University College Dublin.

Barrington-Leigh, C., \& Millard-Ball, A. (2015). A century of sprawl in the United States. Proceedings of the National Academy of Sciences of the United States of America (Early ed.).

Batty, M., \& Longley, P. (1994). Fractal cities: A geometry of form and function. London: Academic Press.

Benfield, F. K., Raimi, M. D., \& Chen, D. D. (1999). Once there were greenfields: How urban sprawl is undermining America's environment, economy and social fabric. Natural Resource Defense.

Bertaud, A. (2001). Metropolis: A measure of the spatial organization of 7 large cities. Available at http://alain-bertaud.com/images/AB_Metropolis_Spatial_Organization. pdf (Accessed: 13th November, 2014)

Besussi, E., Chin, N., M., Batty, \& P., Longley (2010). The structure and form of urban settlements. Remote Sensing of Urban and Suburban Areas, Remote Sensing and Digital Image Processing. EC, SCATTER project.

Bosker, M., \& Marlet, G. (2006). Urban growth and decline in Europe. Discussion paper series nr: 06-18. Utrecht, The Netherlands: Tjalling C. Koopmans Research Institute.

Brueckner, J. K. (2000). Urban sprawl: Diagnosis and remedies. International Regional Science Review, 23(2), 160-171.

Buehlera, R., \& Pucherb, J. (2012). Demand for public transport in Germany and the USA An analysis of rider characteristics. Transport Reviews: A Transnational Transdisciplinary Journal, 32(5), 541-567.

Burchell, R. W., Shad, N. A., Listokin, D., Phillips, H., Downs, A., Siskin, S., ... Gall, M. (1998). The costs of sprawl-Revisited. Transportation Research Board, National Research Concil. 39, . Washington, DC: National Academy Press.
Burton, E. (2000). The Compact City: Just or just compact? A preliminary analysis. Urban Studies, 37, 1969-2001.

Camagni, R., Gibelli, M. C., \& Rigamonti, P. (2002). Urban mobility and urban form: the social and environmental costs of different patterns of urban expansion. Ecological Economics, 40(2), 199-216.

Central Statistics Office (CSO) (2012). Profile 1: Town and country. Stationery Office, Dublin, Ireland: Central Statistics Office.

Chakraborty, M. (2009). An approach towards urban form analysis and land use classification: A case of Ahmedabad, India. (Master's Thesis) The Netherlands: International Institute for Geo-Information Science and Earth Observation Enschede.

Chin, N. (2002). Unearthing the roots of urban sprawl: A critical analysis of form, function and methodology. Centre for Advanced Spatial Analysis, Working Papers Series Paper 47 - Mar 02.

Clifton, K., Ewing, R., Knaap, G., \& Song, Y. (2008). Quantitative analysis of urban form: A multidisciplinary review. Journal of Urbanism: International Research on Placemaking and Urban Sustainability, 1(1), 17-45.

CORINE (Co-ORdinated INformation on the Environment) dataseries (2006). Copernicus Land Monitoring Services. European Commission and European Environment Agency web page: http://land.copernicus.eu/pan-european/corine-land-cover.

Couch, C., Leontidou, L., \& Petschel-Held, G. (2007). Urban sprawl in Europe: Landscapes, land-use change \&' policy. Oxford; Malden: MA, Blackwell.

Cussen, N. (2015). Commentary. In G. Knaap, Z. Nedovic-Budic, \& A. Carbonell (Eds.), Planning for States and Nation-States in the US and Europe. Commentary to Chapter 12 The Irish National Spatial Strategy (pp. 497-502). Cambridge, Massachusetts: Lincoln Institute of Land Policy.

Ellis, G., \& Kim, J. (2001). Dublin - City profile. Cities, 18(5), 355-364.

European Commission (EC) - Directorate General for Regional Policy (20111). Cities of tomorrow challenges, visions, ways forward. Luxembourg: Publications Office of the European Union.

European Environmental Agency/EEA (2006). Urban sprawl in Europe: The ignored challenge. European Environment Agency: Copenhangen.

Eurostat (2014). Population statistics at regional level, Eurostat statistics explained. Online publication. http://ec.europa.eu/eurostat/statistics-explained/index.php/ Population_statistics_at_regional_level\#Population_density (Accessed July 4, 2015)

Ewing, R. (1994). Characteristics, causes, and effects of sprawl: A literature review. Environ Urban Issues, 21(2), 1-15.

Ewing, R. (1997). Is Los Angeles-style sprawl desirable? Journal of the American Planning Association, 63(1), 107-126.

Ewing, R., Pendall, R., \& Chen, D. (2002). Measuring sprawl and its impact. Smart growth America. Available at http://www.smartgrowthamerica.org/ documents/MeasuringSprawl.pdf (Accessed: 13th November, 2014)

Fishman, R. (1987). Bourgeois Utopias: The rise and fall of suburbia. New York: Basic Books.

Foley, W., Williams, B. Cudden, J., \& Shahumyan, H. (2012). Opinion and evidence. socioeconomic data and information relating to development of the Dublin Region. Dublin: Dublin Regional Authority.

Fons, J. (2012). The urban dimension in the EU-LUPA. 4, European Land Use Patterns EULUPA.

Fox-Rogers, L., Murphy, E., \& Grist, B. (2011). Legislative change in Ireland: A Marxist political economy critique of planning law. Town Planning Review, 82(6), 639-668.

Franzini, M., Raitano, M., Callan, T., Nolan, B., Keane, C., Savage, M., ... Marx, I. (2013). Inequality in Europe: What can be done? What should be done? Intereconomics, 48(6), 328-356.

Frenkel, A., \& Ashkenazi, M. (2008). Measuring urban sprawl: How can we deal with it? Environment and Planning B: Planning and Design, 35, 56-79.

Fulton, W., Pendall, R., Nguyen, M., \& Harrison, A. J. (2001). Who sprawls most? How growth patterns differ across the U.S. Washington, D.C.: The Brookings Institution.

Galster, G., Hanson, R., Ratcliffe, M. R., Wolman, H., Coleman, S., \& Freihage, J. (2001). Wrestling sprawl to the ground: Defining and measuring an elusive concept. Housing Policy Debate, 12(4), 681-717.

Gkartzios, M., \& Scott, M. (2009). Countering counter-urbanisation - Spatial planning challenges in a dispersed city-region, the Greater Dublin Area. Town Planning Review, 81(1), 23-52.

Gordon, P., \& Richardson, H. W. (2001). The geography of transportation and land use. In Holcombe R.G., \& S. R. Staley (Eds.), Smarter Growth: Market-Based Strategies for Land-Use Planning in the 21st Century. Chapter 3, pp. Westport, Connecticut: Greenwood.

Grist, B. (2011). Politicians and the Irish planning process: Political culture and impediments to a strategic approach. Journal of Irish and Scottish Studies, 4(2), $159-172$.

Grist, B. (2012). Development plans, core strategies and planning compensation. Irish Planning and Environmental Law Journal, 19(2), 77-85.

Grist, B. (2015). The Irish national spatial strategy. In G. Knaap, Z. Nedovic-Budic, \& A. Carbonell (Eds.), Planning for States and Nation-States in the US and Europe. Chapter 12 (pp. 453-496). Cambridge, Massachusetts: Lincoln Institute of Land Policy.

Hall, P. (2002). Cities of tomorrow: An intellectual history of urban planning and design in the twentieth century. Blackwell.

Hamidi, S., \& Ewing, R. (2014). A longitudinal study of changes in urban sprawl between 2000 and 2010 in the United States. Landscape and Urban Planning, 128, 72-82.

Hess, P. M., Moudon, A. V., Snyder, M. C., \& Stanilov, K. (1999). Site design and pedestrian travel. Transportation Research Record, 1674, 9-19.

Hughes, G., McGinnity, F., O'Connell, P., \& Quinn, E. (2008). The impact of immigration. In Tony Fahey (Eds.), Quality of Life in Ireland (pp. 217-244).

ISTAT (2012). The National Institute of Statistics, Italy. 2012. http://en.istat.it/

Jabareen, Y. R. (2006). Sustainable urban forms: Their typologies, models and concepts. Journal of Planning Education and Research, 26, 38-52. 
Jackson, K. (1985). Crabgrass frontier: The suburbanization of the United States. Oxford, UK: Oxford University Press.

Johnson, M. P. (2001). Environmental impacts of urban sprawl: A survey of the literature and proposed research agenda. Environment E' Planning A, 33(4), 717-735.

Keys, E., Wentz, E. A., \& Redman, C. L. (2007). The spatial structure of land use from 1970 to 2000 in the Phoenix, Arizona, Metropolitan Area. The Professional Geographer, 59(1), 131-147.

Kirby, A. (2008). The production of private space and its implications for urban social relations. Political Geography, 27(1), 74-95.

Kitchin, R., Hearne, R., \& O'Callaghan, C. (2015). Housing in Ireland: From crisis to crisis. NIRSA working paper no. 77. Maynooth: National University of Ireland Maynooth.

Knaap, G. (1998). The determinants of residential property values: Implications for Metropolitan planning. Journal of Planning Literature, 12(3), 267-282.

Knaap, G., Song, Y., \& Nedovic-Budic, Z. (2007). Measuring patterns of urban development: New intelligence for the war on sprawl. Local Environment, 12(3), 239-257.

Kok, H., \& Kovács, Z. (1999). The process of suburbanization in the agglomeration of Budapest. Journal of Housing and the Built Environment, 14, 119-141.

Krisjane, Z., \& Berzins, M. (2012). Post-socialist urban trends: New patterns and motivations for the migration in the suburban areas of Riga, Latvia. Urban Studies, 49(2), 289-306.

Krizek, K. J. (2003). Operationalizing neighborhood accessibility for land use-travel behavior research and regional modeling. Journal of Planning Education and Research, 22, 270-287.

Le Goix, R. (2005). Gated communities, sprawl and segregation. Housing Studies, 20(2), 323-342.

MacLaran, A. (1984). Dublin. Cities, 1(6), 543-550.

Marques de Sá, J. P. (2007). Applied Statistics Using SPSS, STATISTICA, MATLAB and R. Berlin Heidelberg New York: Springer.

McInerney, D. O., \& Walsh, C. (2009). Spatial distribution of urban land-use change in the Dublin city-region: 1990-2006. Irish Geography, 42(2), 207-223.

Meredith, D., \& van Egeraat, C. (2013). Revisiting the National Spatial Strategy ten years on. Administration, 60(3), 3-9.

Moore, N. (2008). Dublin docklands reinvented: The post-industrial regeneration of a European city quarter. Dublin: Four Courts Pr Ltd.

Nechyba, T. J., \& Walsh, R. P. (2004). Urban sprawl. Journal of Economic Perspectives, 18(4), 177-200.

Nedovic-Budic, Z., Slaev, A. D., Krunic, N., \& Petric, J. (2015). Suburbanisation in southeastern Europe: New forms of sprawl on the old continent? Unpublished paper, transitioning towards urban resilience and sustainability, FP7 project. Varna, Bulgaria: Varna Free University.

Nivola, P. S. (1998). Fat city: Understanding American urban form from a transatlantic perspective. Washington, DC: The Brookings Review.

NSS (2002). National spatial strategy for Ireland 2002-2020: People, places and potential. Department of the Environment and Local Government. Dublin: Stationery Office (160 p.)

Patacchini, E., \& Zenou, Y. (2009). Urban sprawl in Europe. Brookings-Wharton Papers on Urban Affairs (pp. 125-149).

Peiser, R. (2001). Decomposing urban sprawl. Town Planning Review, 72(3), 275-298.

Pendall, R. (1999). Do land use controls cause sprawl? Environment and Planning B: Planning and Design, 26, 555-571.

Petrov L., O., Shahunyan, H., Williams, B., \& Convery, S. (2011). Scenario development and indicators to explore the future of Greater Dublin Region in the context of European impact assessment. Procedia - Social and Behavioral Sciences, Scenarios and Indicators Supporting Urban Regional Planning, 21. (pp. 243-252).

Petrov, L. A., Shahumyan, H., Williams, B., \& Convery, S. (2013). Applying spatial indicators to support sustainable urban futures. Environmental Practice, 15(1), 19-32.
Schwarz, N. (2010). Urban form revisited-Selecting indicators for characterising European cities. Landscape and Urban Planning, 96, 29-47.

Shahumyan, H., White, R., Petrov, L., Williams, B., Convery, S., \& Brennan, M. (2011) Urban development scenarios and probability mapping for Greater Dublin Region: The MOLAND model applications. Lecture Notes in Computer Science, 6782(1), 119-134.

Shahumyan, H., Williams, B., \& Foley, W. (2013). Spatial analytic approaches assessing socio-economic development of the Dublin Region compared with other regions in Ireland. Dublin's role in the Irish \& global economy project report. Dublin: Dublin Regional Authority.

Siedentop, S., \& Fina, S. (2012). Who sprawls most? Exploring the patterns of urban growth across 26 European countries. Environment E Planning A, 44(11), 2765-2784.

Song, Y., \& Knaap, G. J. (2004). Measuring urban form - Is Portland winning the war on sprawl? Journal of the American Planning Association, 70(2), 210-225.

Southworth, M., \& Owens, P. M. (1993). The evolving metropolis - Studies of community, neighborhood, and street form at the urban edge. Journal of the American Planning Association, 59(3), 271-287.

Stanilov, K., \& Sýkora, L. (2014). Confronting suburbanization: Urban decentralization in postsocialist Central and Eastern Europe. Oxford: John Wiley \& Sons.

Sudhira, H. S., Ramachandra, T. V., \& Jagadish, K. S. (2003). Urban sprawl: Metrics, dynamics and modelling using GIS. International Journal of Applied Earth Observation and Geoinformation, 5, 29-39.

Sweeney, P. (1998). The Celtic Tiger: Ireland's economic miracle explained. Dublin: Oak Tree Press.

Sweeney, P. (Ed.). (2008). Ireland's economic success: Reasons and lessons. Dublin: New Island Books.

Torrens, P., \& Alberti, M. (2000). Measuring sprawl. Working Paper 27. London: Centre for Advanced Spatial Analysis (CAS).

Tsai, Y. (2005). Quantifying urban form: Compactness versus sprawl. Urban Studies, 2, 141-161.

Wheeler, S. M. (2003). The evolution of urban form in Portland and Toronto: Implications for sustainability planning. Local Environment, 8, 317-336.

Wiechmann, T., \& Pallagst, K. M. (2012). Urban shrinkage in Germany and the USA: A comparison of transformation patterns and local strategies. International Journal of Urban and Regional Research, 36(2), 261-280.

Williams, B. (2011). Planning and development policy and the recession in Ireland. Planning Theory and Practice, 12(3), 441-445.

Williams, B., \& Boyle, I. (2012). The role of property tax incentives in urban regeneration and property market failure in Dublin. Journal of Property Tax Assessment E Administration, 9(2), 5-21.

Williams, B., \& Redmond, D. (2014). Ready money: Residential over-development and its consequences. In A. MacLaran, \& S. Kelly (Eds.), Neoliberal Urban Policy and the Transformation of the City: Reshaping Dublin. Palgrave Macmillan: Basingstoke.

Williams, B., \& Shiels, P. (2000). Acceleration into sprawl: Causes and potential policy responses. Dublin: Economic and Social Research Institute.

Williams, B., Foley, W., Cudden, J., \& Shahumyan, H. (2012). Dublin's role in the Irish and global economy 2012. Working paper report 4. Dublin: Dublin Regional Authority.

Williams, B., Walsh, C., \& Boyle, I. (2010). The development of the functional urban region of Dublin: Implications for regional development markets and planning. Journal of Irish Urban Studies, 7-9, 5-29.

Wilson, B., \& Chakraborty, A. (2013). The environmental impacts of sprawl: Emergent themes from the past decade of planning research. Sustainability, 5(8), 3302-3327.

Yeh, A. G., \& Li, X. (2001). Measurement and monitoring of urban sprawl in a rapidly growing region using entropy. Photogrammetric Engineering and Remote Sensing, 67(1), 83-90. 